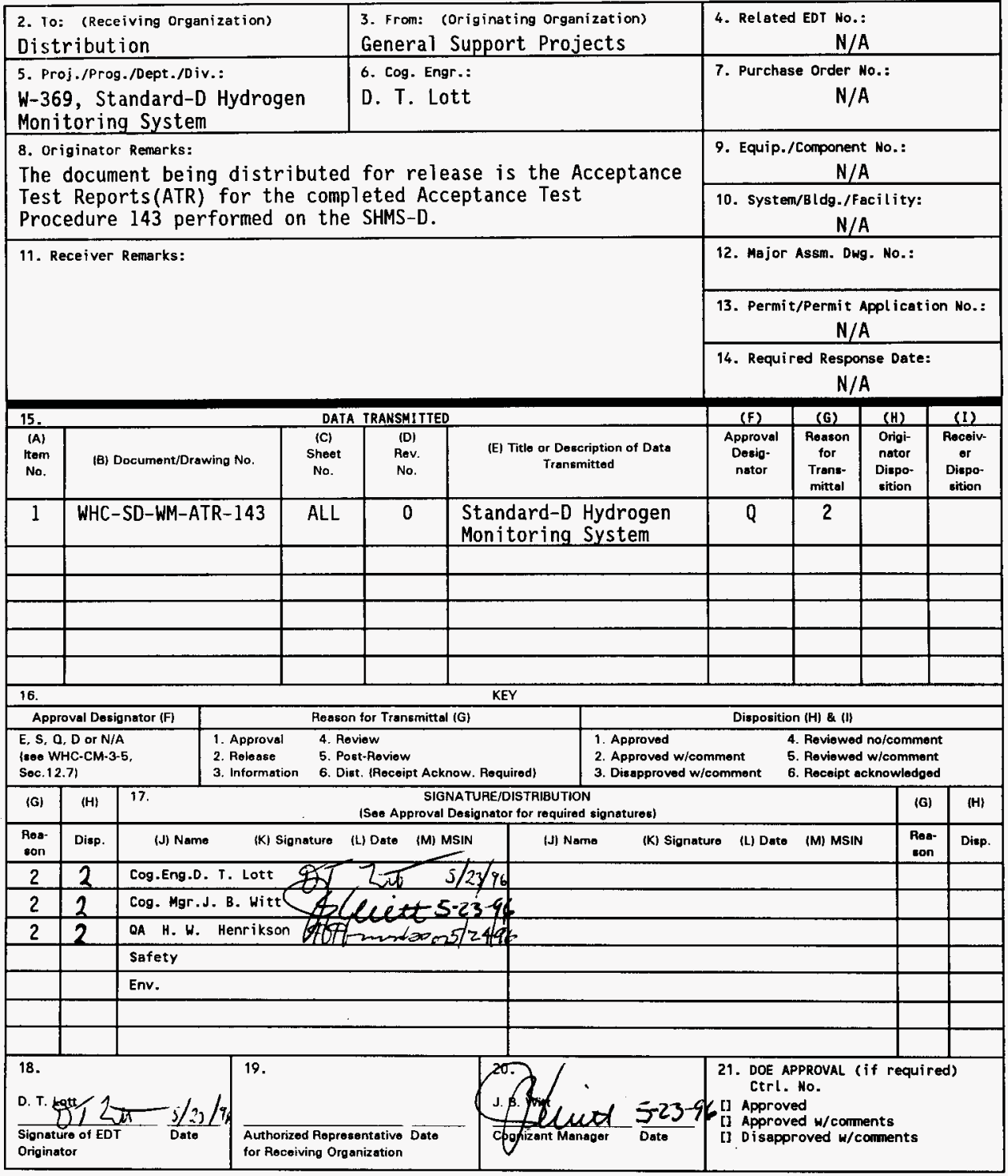




\section{Standard-D Hydrogen Monitoring System Acceptance Test Report}

D. T. Lott

Westinghouse Hanford Co., Richland, WA 99352

U.S. Department of Energy Contract DE-AC06-87RL10930
EDT/ECN: 615502
UC: 2030
Org Code: 8KB20
B\&R Code: EW3120072
Charge Code: N2170
Total Pages:
8570 tims 5 b4/4c

Key Words: Flammable, Ammonia, Stack Monitor, Hydrogen, Monitoring, Standard-D,

Abstract: This document details the results of the field Acceptance Testing of the Standard-D Hydrogen Monitoring System on the waste tank exhaust stacks in 241-AW and 241-AN tank farm. The monitors will be used to measure hydrogen and ammonia from the exhaust stacks.

TRADEMARK DISCLAIMER. Reference herein to any specific comercial product, process, or service by trade name, tradenark, manufacturer, or otherwise, does not necessarily constitute or imply its endorsement, recommendation, or favoring by the United States Goverment or any agency thereof or its contractors or subcontractors.

Printed in the United States of America. To obtain copies of this document, contact: WHC/BCS Document Control Services, P.O. BOX 1970, Mailstop H6-08, Richland HA 99352, Phone (509) 372-2420; Fax (509) 376-4989.
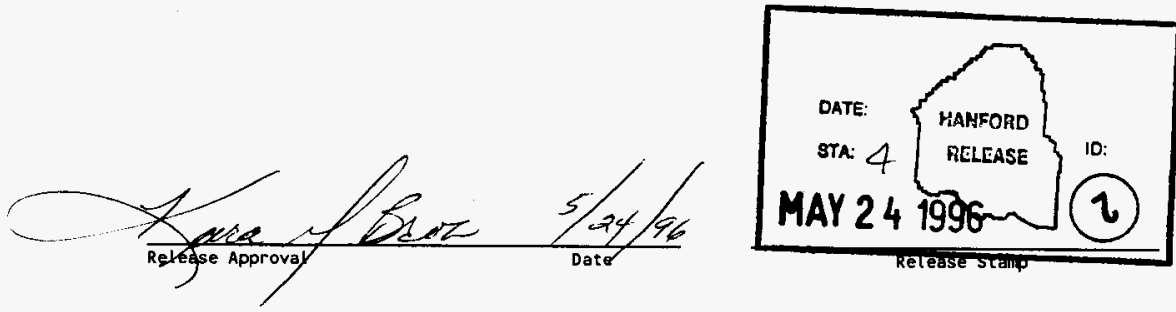

Approved for Public Release 
WHC-SD-WM-ATR-143

Rev. 0

Page 1

STANDARD-D HYDROGEN MONITORING SYSTEM

ACCEPTANCE TEST REPORT

WHC-SD-WM-ATR-143

REV. 0

APPROVAL DESIGNATOR Q

ISSUED BY

ENVIRONMENTAL PROJECTS

MAY 1996 
WHC-SD-WM-ATR-143

Rev. 0

Page 2

TABLE OF CONTENTS

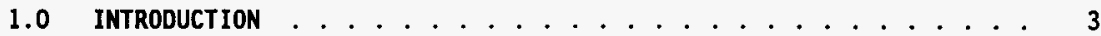

2.0 DESCRIPTION OF TEST . . . . . . . . . . . . . . . . . 3

3.0 TEST METHOD AND TEST EQUIPMENT . . . . . . . . . . . . 3

4.0 TEST RESULTS AND CONCLUSIONS ................. 3

5.0 DISPOSITION OF TEST ITEMS ................ 3

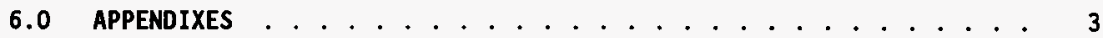

APPENDIX A (241-AW EXHAUSTER STACK) . . . . . . . . . . A-1

APPENDIX B (241-AN EXHAUSTER STACK) $\ldots \ldots \ldots$ 


\subsection{INTRODUCTION}

Project W-369, Phase II installed Standard-D Hydrogen Monitoring Systems (SHMS-D) on the waste tank exhauster stacks in 241-AW and 241-AN tank farms. ATPs were performed and completed for each installation. ATP performance was controlled by the tank farm work packages. These completed ATPs are transmitted by EDT 615502 as an Acceptance Test Report (ATR) in accordance with WHC-6-1, EP4.2 and EP 1.12 .

\subsection{DESCRIPTION OF TEST}

The performance of WHC-SD-WM-ATP-143 was used to qualify the SHMS-Ds installed on the waste tanks. The ATP was used to assure that the systems's wiring and components were properly installed and labeled. Electrical and pneumatic tests were also performed to assure system integrity.

\subsection{TEST METHOD AND TEST EQUIPMENT}

The test verified that the cabinets were constructed and installed per the appropriate design assemble and installation drawings. The test checked the electrical and pneumatic connections to verify functional correctness, but did not perform formal operation testing to qual ify the system for data collection. The operational calibrations were subsequently performed under approved maintenance procedures.

\subsection{TEST RESULTS AND CONCLUSIONS}

The tests were performed and noted without exceptions as indicated within the Test Log for the monitor.

\subsection{DISPOSITION OF TEST ITEMS}

The equipment inspected and tested by WHC-SD-WM-ATP-143 performed as expected, and is accepted for field operation.

\subsection{APPENDIXES}

The originally completed WHC-SD-WM-ATP-143 is included as appendixes to this test report. 
WHC-SD-WM-ATR-143

Rev. 0

PageAl

APPENDIX A (241-AN EXHAUSTER STACK) 
TEST EXECUTION SHEET

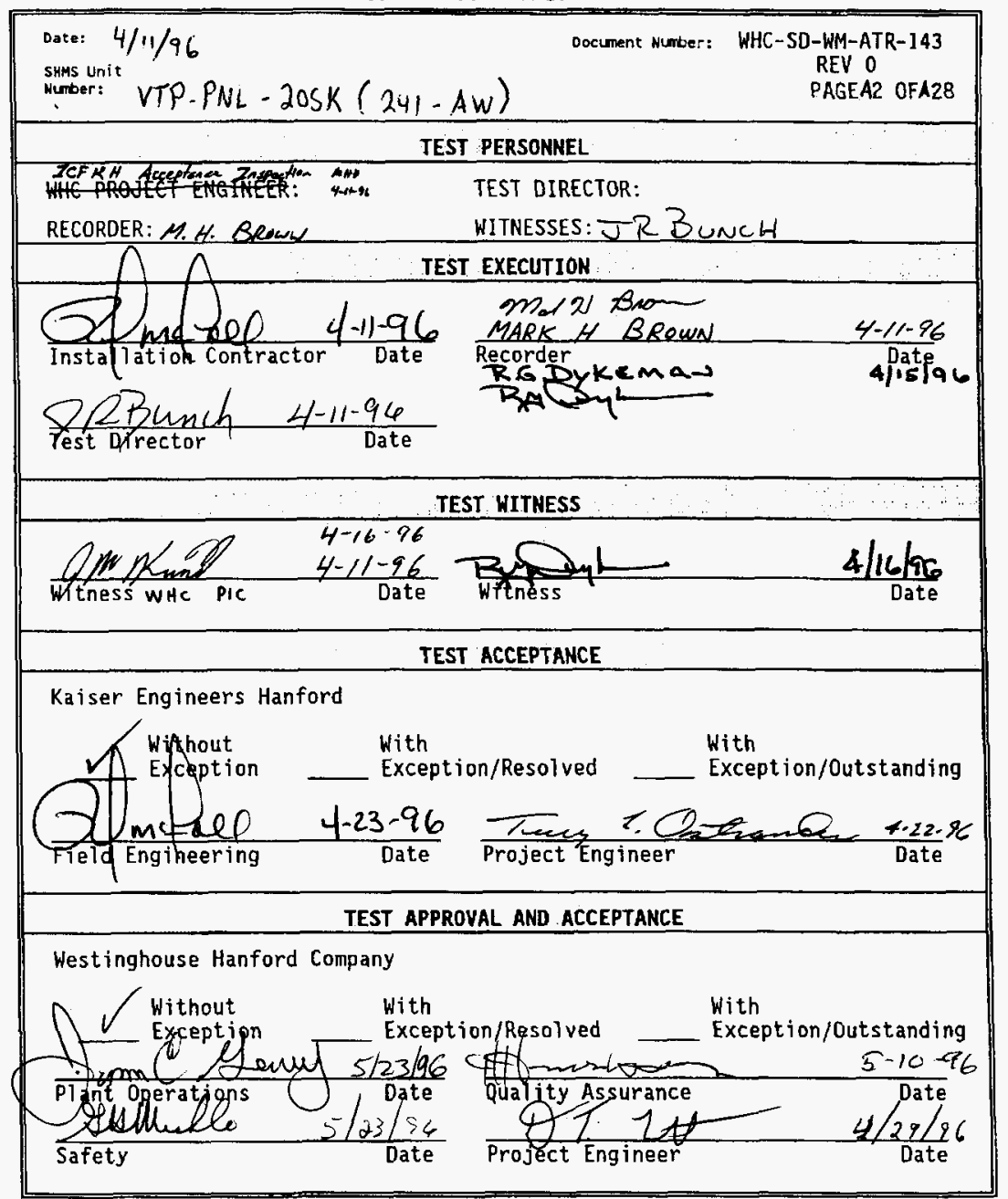


WHC-SD-WM-ATR-143

REV. 0

PAGEA3 OFA28

TABLE OF CONTENTS

TEST EXECUTION SHEET . . . . . . . . . . . . . . . . . . . . . 2

1.0 PURPOSE ............................ . . . . . .

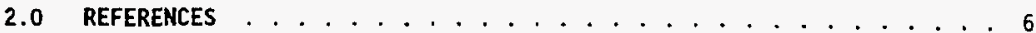

2.1 DRAHINGS . . . . . . . . . . . . . . . . . . 6

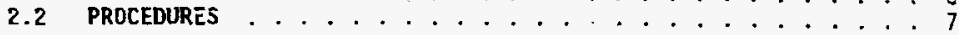

3.0 RESPONSIBILITIES . . . . . . . . . . . . . . . . . . . 7

3.1 WHC PROJECT ENGINEER .................... . . . 7

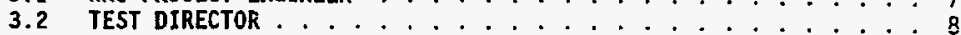

3.3 NITNESSES . . . . . . . . . . . . . . . . . . . . . . . 9

3.4 RECORDER . . . . . . . . . . . . . . . . . . . . 9

3.5 CONSTRUCTION CONTRACTOR ................. 10

3.6 OCCUPATIONAL SAFETY AND HEALTH . . . . . . . . . . . . . . 11

4.0 ACCEPTANCE test PRocedure Change CONTRO_ . . . . . . . . . . . . . II

5.0 TEST EXECUTION . . . . . . . . . . . . . . . . II

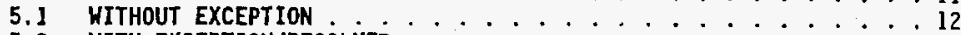

5.2 WITH EXCEPTION/RESOLVED ................... 12

5.3 WITH EXCEPTION/OUTSTANDING . . . . . . . . . . . . . . 12

6.0 RECORDING AND RESOLVING EXCEPTIONS ................. 12

6.1 GENERAL . . . . . . . . . . . . . . . . . . 13

6.2 RECORDING . . . . . . . . . . . . . . . . 13

6.3 RETEST/RESOLUTION . . . . . . . . . . . . . . . . 13

6.4 APPROVAL AND ACCEPTANCE ................. 13

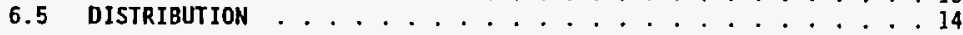

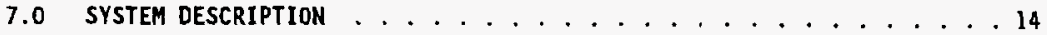

8.0 TEST CONDITIONS AND EQUIPNENT REQUIRED . . . . . . . . . . . . . 14

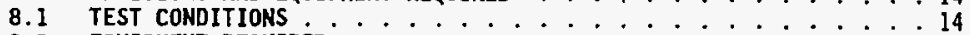

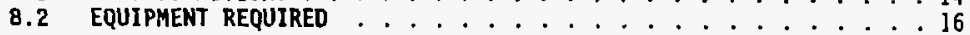

9.0 ELECTRICAL SYSTEMS . . . . . . . . . . . . . . . . . . 17

9.1 SHMS POKER SUPPLY . . . . . . . . . . . . . . . . . 17

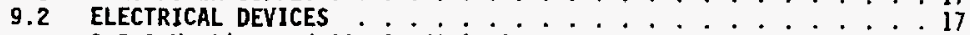

9.2.1 Heating and Air Condtioning . . . . . . . . . . . . . 17

9.2.2 Sample Pump . . . . . . . . . . . . . . . . . . 18

9.2.3 Panel Power Supply ................... 19

9.2.4 Cabinet Instrumentation . . . . . . . . . . . . 19

9.2.4.1 Isolation Transformer . . . . . . . . 19

9.2.4.2 DC Power . . . . . . . . . . . . 19

9.2.4.3 Flow Al arm System . . . . . . . . . 20 


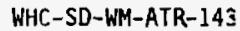

REV. 0

PAGEA 4 OFA2

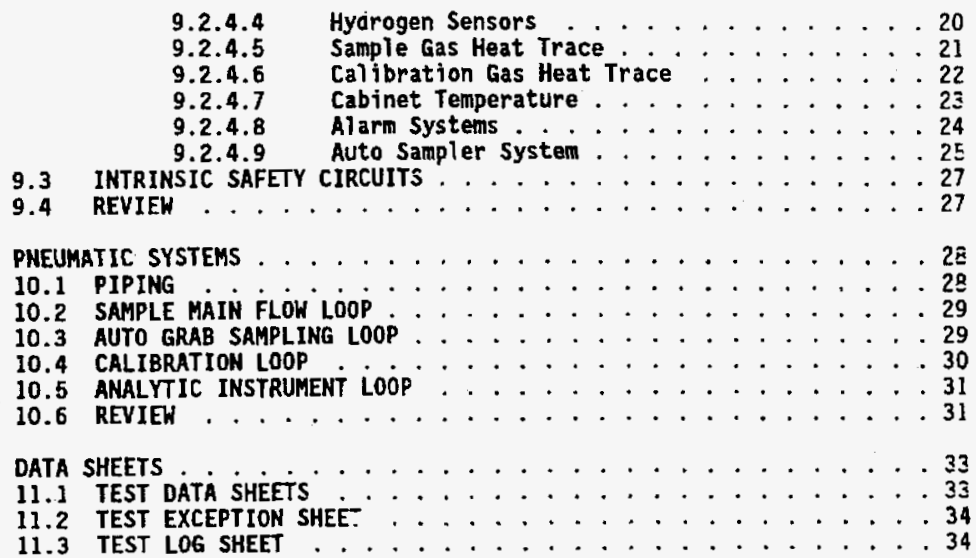

APPENDIX A: TEST DATA SHEETS ...................... . . I

APPERDIX B: TEST EXCEPTION SHEETS . . . . . . . . . . . . . . . I

APPENDIX $c$ : TEST LOG SHEET . . . . . . . . . . . . . . . . I 
WHC-SD-WM-ATR-143

REV. 0

PAGE 5 OF $2 E$

\section{STANDARD-D HYDROGEN MONITORING SYSTEM}

ACCEPTANCE TEST PROCEDURE

\subsection{PURPOSE}

The purpose of this document is to demonstrate that the Standard-D Hydrogen Monitoring System is constructed as intended by design. This document does not include testing of ammonia or organic sampling equipment. Additions of this type of equipment will require a seperate test document.

\subsection{REFEREMCES}

\subsection{DRAWINGS}

- H-14-100295, Standard-D Hydrogen Monitoring System Piping \& Instrumentation Diagram.

- H-14-100296, Standard-D Hydrogen Manitoring System Equipment Arrabgement.

- H-14-100297, Standard-D Hydrogen Monitoring System Dne-Line, Elementary Diagrams.

- H-14-100298, Standard-D Hydrogen Monitoring System Cabinet Assembly.

- H-14-100299, Standard-D Hydrogen Monitoring System Wiring Diagram.

- H-14-100300, Standard-D Hydrogen Monitoring System Interior Panels $\&$ Brackets.

- H-14-100301, Standard-D Hydrogen Monitoring System Cabinet Modifications.

- H-14-100302, Standard-D Hydrogen Monitoring System Loop Diagrams.

- K-14-100303, Standard-D Hydrogen Monitoring System PLC Ladder Diagram.

- H-14-100304, Standard-D Hydrogen Monitoring System Instrument Panel Assembly.

- H-2-818214 Standard-B Hydrogen Monitoring System Gas Bottle Rack

- H-2-818220, Standard-B Hydrogen Monitoring System Sample Pump Stand Assembly. 
WHC-SD-WM-ATR-143

REV. 0

PAGE 6 OF 28

\subsection{PROCEDURES}

- WHC-CM-4-3, Volume 1, Program E-2, Electrical Safetr Practices.

\subsection{RESPONSIBILITIES}

Each company or organization participating in the conduct of this ATf will designate personnel to assume tine responsibilities and duties as defired herein for their respective roles. The names of these designees shall be provided to the Recorder for listing on the Recorder's copy of the Test Execution Sheet prior to the performance of any part of this ATF.

\subsection{WHC PROJECT ENGINEER}

3.1.1 Designate a Test Director.

3.1.2 Coordinate testing with facility management.

3.1.3 Act as liaison between the participants in acceptance testir:

3.1.4 Distribute tine approved testing schedule as soon as possible, but at least two days prior to testing.

3.1.5 Ensure field testing and inspection has beer: completed.

3.1.6 Schedule and conduct a pre-ATP meeting with tes: participants prior to start of testing.

3.1.7 Notify the persons performing and witnessing the test prior to the start of testing.

3.1.8 Notify all concerned parties when a change is made in the testing schedu'e.

3.1.9 Sign Test Execution Sheet when ATP is approved and accepted.

3.1.10 Take necessary action to clear exceptions to the AT?.

3.1.11 Sign Exception Sheet when exception has been resolved.

3.1.12 Provide a distribution list for the approved and accepted ATP. 


\subsection{TEST DIRECTOK}

3.2.1 Coordinate all acceptance testing.

3.2.2 Confirm that fieid testing and inspection of the system or portion of tine system to be tested has beer. completed.

3.2.3 Stop any test which may cause damage to the system until the test procedure has been reviseci.

3.2.4 Approve fielo cranges to the ATP.

3.2.5 Obtain revisions to the ATP, as necessary, to compiy with authorized field changes or to accommodate existing field conditior.s.

3.2.6 Evaluate recorded aata, discrepancies, and exceptions.

3.2.7 Obtain from the WHC Project Engineer, any information or changes necessary to clear or resolve objections.

3.2.8 Sign Test Execution Sheet when ATP has been performed.

3.2.9 Sign Test Exception Sheet when retest has been executed and accepiec.

3.2.10 Obtain required signatures on the ATP Master prior to reproduction and distribution.

3.3 WITHESSES (Provided by Participating Organizations)

3.3.1 Witness the tests.

3.3.2 Evaluate results of testing.

3.3.3 Assist the Test Director when requestec.

3.3.4 Sign Test Exception Sneet as a Wirness.

3.3.5 Sign Test Exception Sheet as a Witness when retest tas been executed and accepted.

3.4 RECORDER (Appointed by Test Director, Provided by KEH if KEH installed equipment)

3.4.1 Record names of all designated personnel on Recorder's copy of ATP prior to start of testing. 
3.4.3 Sign the Test Exception Sheet as the Recorder.

3.4.4 Initial and date every test step on the Recorder's copy as it is completed, next to the step number or or a table, when provided. On tables where there is nc: room for both the initial and the daie, oate may be entered in space provided at bottom of columr.

3.4.5 Record authorized field changes to the ATF.

3.4.6 Recora exceptions and test steps that are not performed on the Test Exception Sheet. have tine information transferred in ink or typed to the Master Exception Sineet(s). Additional Exception Sneets are to be added as neegec.

3.4.7 Orally notify the Test Director at time the objectior: is made.

3.4.8 Assign page number to Data Sheets and Exceptior Sheets, after ATP is complete. Record Page numbers for these items and mace corrections, as necessary, tc page numbers shown for these pages in the inciex.

3.4.9 Transfer the final test results with Recorder's signature and dates for each step to the Master in ink or type. Submit the completed Master to the Test Director for approval signatures and distrijution. Retain the Recorder's copy and copy of the Master in the field project files. IF the cabinet is installed and tested oy WHC, a seperate Master test copy is not required, tine Recorder's copy may be used.

\subsection{CONSTRUCTION CONTRACTOP.}

3.5.1 Organize and perform this acceptance test under coordination of the Test Director.

3.5.2 Confirm that all equipment required for performing this test (as 1 isted in Section 8.2) will be available at start of testing.

3.5.3 Provide equipment required for performing this acceptance test, which has not been designatec as being provided by otners.

3.5.4 Request in writing from the Project Engineer those services, materials, or equipment that have been: 
WHC-SD-WM-ATP-143

REV. 0

PAGE 9 OF 28

designated as being supplied by the Department of Energy (DOE) or others.

\subsection{OCCUPATIONAL SAFETY AND HEALTH}

Individuals shall carry out their assigned work in a safe manner to protect themselves, others, and the equipment from undue hazards and to prevent damage to property and environment. Facility line managers shall assure the safety of all activities within their areas to prevent injury, property damage, or interruption of operation. Performance of test activities shall always include safety and health aspects as delineated in the Operations Manuals and as directed by the WHC Project Engineer. Any hazard identified during the performance of the ATP shall be reported to the manager of Waste Tank Safety Assurance.

\subsection{ACCEPTANCE TEST PROCEDURE CHANGE CONTROL}

Acceptance testing is to be conducted in accordance with the steps and requirements specified in this procedure. Any required changes must be authorized in accordance with Section 3.2 and with approved change control procedures.

\subsection{TEST EXECUTION}

The acceptance test procedures detailed in Sections 9.0 and 10.0 shall be performed in sequential steps starting with Section 9.0. As required by Section 3.4, the Recorder will initial and date every test step in the space provided on the Recorder's copy of the ATP as each step is completed. Any step that requires verification must al so be recorded on the Test Data Sheet.

\subsection{WITHOUT EXCEPTION}

5.1.1 Check applicable space on Test Execution Sheet to show that the ATP has been performed and no exceptions have been recorded.

5.1.2 Sign and date Test Execution Sheet in the spaces provided.

5.1.3 Distribute requisite copies and send master of ATP to the elient. 
WHC-SD-WM-ATR-143

REV. 0

PAGE 10 OF 28

A

\subsection{WITH EXCEPTION/RESOLVEC}

5.2.1 Check applicable space on Test Execution Sheet to show that the ATP has been performed witn exceptions recorded and resolvec.

5.2.2 Sign and date Test Execution Sheet in the spaces provided.

5.2.3 Distribute requisite copies and send master of ATP to the clier:

\subsection{HITH EXCEPTION/OUTSTANDINS}

5.3.1 Check applicable space on Test Execution Sheet to show that the ATP has been performed with exceptiors recorded, part or all of wicicn are presently outstanding, unresolved,

5.3.2 Sign and date Test Execution Sheet in the spaces provided.

5.3.3 Distribute requisite copies and send master of ATP to the clier:.

\subsection{RECORDING AND RESOLVING EXCEPTIONS}

\section{I GENERAL}

Exceptions to the ATP are sequentialiy numbered and recorded or: individual Exception Sheets. Tnis enables case-by-case resolution, recording, approval, and distribution of each exception.

\subsection{RECORDING}

6.2.1 Number each exception sequentially as it occurs anc record it on an Exception Sriee:.

6.2.2 Enter name and organization of objecting party for each exceptior.

6.2.3 Enter planned action to resolve each exception when such determination is mace. 


$$
\begin{array}{r}
\text { WhiC-SD-WM-ATR-143 } \\
\text { REV. } 0 \\
\text { PAGE } 11 \text { OF } 28 \\
\text { A A }
\end{array}
$$

\section{、 6.3 RETEST/RESOLUTION}

6.3.1 Record the action taken to resolve each exception. Action taken may not be the same as planned action.

6.3.2 When action taken results in an acceptable retes:, sign and date Retest Execution and Acceptance sectior. of the Exception Sheet.

6.3.3 When action taken does not involve an acceptable retest, strike out the Retest Execution and Acceptance section of the Exception Sheet. Resolve exception as shown under 6.4 below.

\subsection{APPROVAL AND ACCEPTANCE}

6.4.1 The Project Engineer provides final approval and acceptance of exception by checking one of the following on Exception Sheet:

- Retest Approved and Accepted: Applicable when Retest Execution and Acceptance section is completed.

- Exception Accepted-As-Is: Requires detalled explanation.

- Other: Requires detailed explanation.

6.4.2 The Project Engineer signs and dates the Exception Sheet and obtains other internal approval, if required.

\subsection{DISTRIBUTION}

Distribute requisite copies of completed Exception Sheets to the client.

\subsection{SYSTEM DESCRIPTION}

The primary function of the Standard Hydrogen Monitoring System is to monitor specifically for hydrogen in the waste tank atmosphere which may al so contain (but not be limited to) unknown quantities of air, nitrous oxide, ammonia, water vapor, carbon dioxide, carbon monoxide, and other gaseous constituents. 
WHC-SD-WM-ATP-143

REV. 0

PAGE 12 OF 28

- The SHMS will consist of hydrogen specific monitors, a grab sampler ic collect samples for laboratory analysis, and the gas sample collection sysiem necessary to support the operation of the instrumentation. This system wil? be located in a cabinet placed at the tank of interest.

\subsection{TEST CONDITIONS AND EQUIPNENT REQUIRED}

\subsection{TEST CONDITIONS} testing.

The following conditions shall exist at the start of the acceptance

mas.
$4-1.1 .96$$\quad \begin{aligned} & \text { Systems being tested have been inspected for } \\ & \text { workmanship and for compliance with design. }\end{aligned}$

m.s.s $\quad$ 8.1.2

$4-14-96$

Continuity and megger tests have been performed or portions of the electrical and instrument systems being tested, as required.

Mas 8.1 .3

Leak tests on the pneumatic systems have been

$4-11-96$ performec.

8.1.4 The following circuit breakers and fuses are open CB-1 throught $\mathrm{CB}-7$

FU-1 through FU-13

aqd

24208.1 .5

All test instruments have a currently valid calibration stamp attached that indicates a calibration traceable to the National Institute of Standards and Technology.

zuxs 8.1.6

Personnel responsible for directing and witnessing the performance of the tests described in this ATP have read and understand appropriate certified vendc: information (CVI) pertaining to the operation of the equipment to be tested.

8.1.7 The following sample lines/valves are CAPPED/CLOSED,

$M$

$S V-* 03$

$S V-\star 05$

$S V-\star 07$ throught $S V-* 10$

SV $-\star 12$

SV-*15

SV-*]6

SV $-* 18$

$2 V-{ }^{2} 19$ 
WHC-SD-WM-ATR-143

REY. 0

PAGE 13 OF $2 E$

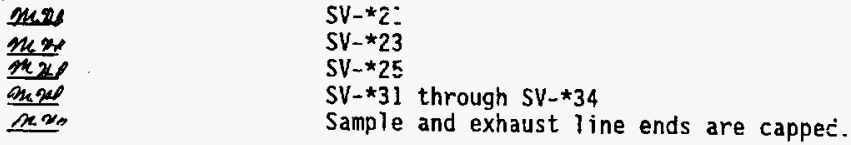

8.1.8 The following sample line valves are OPEN

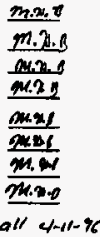

$$
\begin{aligned}
& S V-* 06 \\
& S V-* 11 \\
& S V-\star 17 \\
& S V-\star 20 \\
& S V-\star 22 \\
& S V-\star 24 \\
& F I V-\star 52 \\
& F I V-* 56
\end{aligned}
$$

Check that all prerequisites have been met.

Man OP Bu

\subsection{EQUIPMENT REQUIRED}

The Contractor shall supply all test equipment unless otherwise noted. 
WHC-SD-WH-ATR-143

REV. 0

PAGE 14 OF $2 E$

A A

\subsection{ELECTRICAL SYSTEMS} properly.

This procedure will demonstrate that all electrical devices function

\subsection{SHMS POWER SUPPLY}

$\frac{M Q 1 . B}{4-1-46}$

$\frac{20910}{4-1-96}$

$\frac{2+2.8}{4-9-96}$

\subsection{ELECTRICAL DEVICES}

\subsubsection{Heating and Air Conditioning}

20x/9

9.2 .1 .1

Adjust Air Conditioner $(A C-\star 60)$ temperature control to a value below ambient temperature.

now

andes

Mne

map

xQ9OS

120

all $4-11-76$

9.1.1 Verify resistance Detween system ground and cabine: enclosure is less than one (i) onr. System. Refer to H-14-100297, Standard-D hyoragen Monitoring System One Line \& Elementary Diagrams.

9.1.3 Verify line voltages, $L 1, L 2$, and $N$, at terminal block.

9.2.1.2 Adjust Heater $(H T R-\star 60)$ temperature control to a value below ambient temperature.

9.2.1.3 Switch circuit breaker CB-1 to the CLOSED position.

9.2.1.4 Verify Air Conditioner is operating and Heater is off.

NOTE: If ambient temperature is below Air Conditioner's minimum setting, a heat gun may be used to heat the $A / C$ 's temperature probe.

9.2.1.5 Adjust Air Conditioner temperature control to a value above ambient temperature.

9.2.1.6 Verify Air Conditioner compressor turns OFF. NOTE: Air Conditioner fan may still operate.

9.2.1.7 Adjust Heater temperature control to a value above ambient temperature. 
WHC-SD-WM-ATP-143

REV. 0

PAGE 15 OF 28

A $A$

2nos

max

axpes

Ames

Mins

PYx

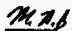

ax

xD B

mente

all $4-11-96$

240.6
9.2.1.8 Verify Heater operates.

9.2.1.9 Adjust Air Conditioner temperature control to a value beiow ambient temperature.

9.2.1.10 Verify Air Conditioner compressor turns ON anc Heater power is removed by the CR- $* 60$ relay.

NOTE: Heat may still radiate from Heater.

9.2.1.11 Adjust Heater temperature control to $80^{\circ} \mathrm{F}\left(27^{\circ}\right.$ C).

9.2.1.12 Adjust Air Conditioner temperature cantrol to $90^{\circ} \mathrm{F}\left(32^{\circ} \mathrm{C}\right)$.

9.2.1.13 Switch circuit breaker CB-1 to the OPEN position.

\subsubsection{Sample Pump}

9.2.2.1 Disconnect sample line outlet from sample pump $P-\star 50$ at the closest convenient Swagelok fitting.

9.2.2.2 Switch circuit breaker CB-3 to the CLOSED position.

9.2.2.3 Verify pump turns $O N$.

9.2.2.4 Switch circuit breaker CB-3 to the OPEN position.

9.2.2.5 Reconnect sample line outlet to sample pump per manufacturer's guidance.

\subsubsection{Panel Power Supply}

9.2.3.1 Switch circuit breaker CB-6 to the CLOSED position.

9.2.3.2 Turn cabinet enclosure light switch to the $O N$ position.

9.2.3.3 Verify cabinet enclosure light is $0 N$.

9.2.3.4 Verify power is being supplied to the cabinet receptacle and record voltage readings. 
WHC-SD-WM-ATR-143

REV. 0

PAGE $_{4} 16$ OF 28

200

$4 x$

$M D, P$

Mns

20.23

$m 2.8$

20013

2uss

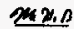

$\frac{x+x}{2 x+4}$

anseres

211.21 $x$

$a / 14-11.96$
9.2.3.5 Test GFI capabilicy jy depressing "TEST" bution on receptacle. Verify zero voliage across receptacle hot and neutral. Reset GFI receptacle.

9.2.3.6 Turn cabinet enclosure 1ighi switc; to the or= positior.

9.2.3.7 Switch circuit breaker CB-6 to the OPEN position.

\subsubsection{Cabinet Instrumentation}

\subsubsection{Isolation Transformer}

9.2.4.1.1 Switch circuit breaker CB-7 to the CLOSE? positior.

9.2.4.1.2 Verify power is being supplied to tin isolation transformer ISO XFMER. Record primary and secondary vo $0^{\circ}$ tages.

\subsubsection{DC Power}

9.2.4.2.1 Set fused switch $F_{0}-1$ to the CLOSED position.

9.2.4.2.2 Verify power is jeing supplied to the $D C$ power source PS- $\star 50$. Record $A C$ input anc DC output voltages.

\subsubsection{Flow Alarm Syster.}

9.2.4.3.1 Set fused switch FU-13 to the CLOSEC position.

9.2.4.3.2 Set fused switch Fu-3 to the CLOSEC position.

9.2.4.3.3 Visually verify instruments are operating: Transmitter FIT-*5T, Flow Al arm FSL-*57.

9.2.4.3.4 Verify zero voltage between PLC YYC-*aI Input Numier 2 and PLC $120 \mathrm{~V}$ Common.

9.2.4.3.5 Set fused switch FU-3 to tie OPESi position. 
WHC-SD-WM-ATR-143

REV. 0

PAGE 17 OF 28

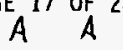

matse

9.2.4.3.6 Set fused switch FU-13 to the OPEN position.

\subsubsection{Hydrogen Sensors}

M.2.

9.2.4.4.1 Set fused switcines FU-2, FU-4, FU-5, ar: FU-10 to the CLOSED position.

9.2.4.4.2 Visually verify instrument displays are operating:

$\frac{\operatorname{man} \theta}{\frac{\max x \phi}{\operatorname{man}}}$ Transmitter NIT-*54, Transmitter NIT-*55, Recorder NR- $\star 54$.

$2 \times 24$

9.2.4.4.3 Verify $120 \mathrm{~V}$ present between PLC YYC-*01 Input Number 0 and PLC $120 \mathrm{~V}$ Common and Input Number 1 and PLC $120 \mathrm{~V}$ Common.

maxh

9.2.4.4.4 Set fused switches FU-2, FU-4, FU-5, and FU-10 to the OPEN position.

\subsubsection{Sample Gas Heat Trace}

NOTE: These steps must be done in an expedited manner. The Heat Trace circuit may cause the sample gas temperature to rise at a fast rate. Adjust setpoints accordingly in order to prolong the test.

$\operatorname{sen}$

MU.

M.s

m.

IxN/

a/l $4-1 /-46$
9.2.4.5.1 Set fused switch FU-6 to the CLOSEO position.

9.2.4.5.2 Set circuit breaker CB-5 to the CLOSED position.

9.2.4.5.3 Visually verify controller TIC-*50 display is operating.

9.2.4.5.4 Adjust controlier temperature setpoint number 1 to a value at least 20 degrees above ambient temperature as indicated by the controller.

9.2.4.5.5 Adjust controller temperature setpoint number 2 to a value 5 degrees less than setpoint number 1 . 
WHC-SD-WM-ATR-145

REV. 0

PAGE $_{A} 18$ OF $2 E$

mase

MxPe

$m \times e$

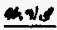

xㅗ잉

ank

exN

재는

$4 \pi$

소차

240

$4114-11-96$
9.2.4.5.6 Verify no AC voltage present between PLi $Y Y C-* 01$ Input Number 5 ano PLC $120 \mathrm{~V}$

Common.

9.2.4.5.7 Visually verify operation of neat trace HT-*50 circuit. Temperature value of sample gas should begin increasing. Record initial temperature and increased temperature of nominally 10 degrees.

9.2.4.5.8 Adjust setpoint 2 to 20 degrees below indicated temperature.

9.2.4.5.9 Verify $120 \mathrm{~V}$ present between PLC YYC-*C? Input Number 5 and $\mathrm{PLC} 120 \mathrm{~V}$ Common.

9.2.4.5.10 Reset controller cemperature setpoint 1 to $125^{\circ} \mathrm{F}\left(52^{\circ} \mathrm{C}\right)$ and setpoint 2 to $65^{\circ}=$ $\left(18^{\circ} \mathrm{i}\right.$.

9.2.4.5.11 Set fused switch FJ-6 to the OPEN position.

\subsubsection{Calibration Gas Heat Trace}

NOTE: These steps must be done in an expediteo manner. The Heat Trace circuit may cause the calibratior gas temperature to rise at a fast rate. Adjus: setpoints accordingly in order to prolong the test.

9.2.4.6.1 Set fused switch FU-7 to the CLOSEC position.

9.2.4.6.2 Visually verify controller TIC $-* 56$ disp ${ }^{-}$ay is operating.

9.2.4.6.3 Adjust controller iemperature setpoint number 1 to a value at least 20 degrees above ambient temperature as indicated by the controller.

9.2.4.6.4 Adjust controller temperature setpoint number 2 to a value 5 degrees less than setpoint number 1 .

9.2.4.6.5 Verify no AC voltage present between PLC YYC-*0l Input Number 4 and PLC 120V Common. 
WHC-SD-WM-ATR-143

REV. 0

PAGE 19 OF 28

maxp

max

uㅐe

pure

$2 x, 2$

240

max

Mns

que

mine

nuts

Qn+10

$4-11-96$
9.2.4.6.6 Visually verify operation of neat irace HT-*56 circuit. Temperature value o" calibration gas should begin increasirg. Record initial temperature and increase: temperature of nominally 10 degrees.

9.2.4.6.7 Adjust setpoint 2 to 20 oegrees beisis indicated temperature.

9.2.4.6.8 Verify $120 \mathrm{~V}$ present between PLC YYC- $* 0$ : Input Numser 4 and PLC $120 \mathrm{~V}$ Common.

9.2.4.6.9 Reset controller iemperature setpoint 1 to $125^{\circ} \mathrm{F}\left(52^{\circ} \mathrm{C}\right)$ and setpoint 2 to $65^{\circ}=$ $\left(18^{\circ} \mathrm{i}\right)$.

9.2.4.6.10 Set fused switch FU-7 and circuit breaken CB-5 to the OPEN position.

\subsubsection{Cabinet Temperaiure}

9.2.4.7.1 Set fused switch FU-8 to the CLOSEO position.

9.2.4.7.2 Visually verify temperature indicator TIS*62 display is operating.

9.2.4.7.3 Adjust controller temperature setpoir:number 1 to a value at least 20 degrees above ambient temperature as indicated by the controller.

9.2.4.7.4 Adjust controller temperature setpoint number 2 to a value 20 degrees less than the indicated ambient temperature.

9.2.4.7.5 Verify $120 \mathrm{~V}$ AC voltage present between PLC YYC-*01 Input Number 3 and PLC $120 \mathrm{~V}$ Common.

9.2.4.7.6 Adjust setpoint 2 to 10 degrees above indicated temperature.

9.2.4.7.7 Verify zero voltage present between PLC YYC-*01 Input Number 3 and PLC $120 \mathrm{~V}$ Common. 
WHC-SD-WM-ATR-143

REV. 0

PAGE 20 OF 28

quepop

quen

$x \in 26$

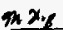

mans

$\underline{\mu x x_{s}}$

$R_{m a s} 4 / 14 k 6$

$\frac{R(2)}{4 \mid 16 \text { R6 }}$

Tex 4/kata

RGO4/16ta

BeP4liche

RoD 4/14/96

RaD 4/16/96

$\operatorname{Ran} 4 / 16 k 6$
9.2.4.7.8 Adjust controller temperature setpoir:number 2 to a value 20 degrees less thar the indicated ambient temperature.

9.2.4.7.9 Verify $120 \mathrm{~V} A C$ voltage present between $\mathrm{PLC}$ YYC-*01 Input Number 3 and PLC $120 \mathrm{~V}$ Commor.

9.2.4.7.10 Adjust setpoint 1 to 10 oegrees Deion indicated temperacure.

9.2.4.7.11 Verify zero voliage present at PLC YYC-*01 Input Number 3 and PLC $120 \mathrm{~V}$ Common.

9.2.4.7.12 Reset controller temperature setpoint 1 ic $100^{\circ} \mathrm{F}\left(38^{\circ} \mathrm{C}\right)$ and setpoint 2 to $75^{\circ} \mathrm{F}$ $\left\{24^{\circ} \mathrm{C}\right\}$.

9.2.4.7.13 Set fused switch FU-8 to the OPEN positior.

\subsubsection{Alarm Systems}

9.2.4.8.1 Set fused switch FU-9 and FU-10 to the CLOSED positior.

9.2.4.8.2 Depress Alarm Reset $P B-\star 51$ followed by the Horn Acknowleage pushbutton $\mathrm{PB}-\star 50$. (Due to lack of operating inputs the PLC may interpret alarm conditions exist.)

9.2.4.8.3 Depress and hold Alarm Test pushbutton PB*52. Verify the following conditiors exis::

Horn, YAH-*50, is ON.

High Hydrogen Beacon $\mathrm{NAH}-\star 55$ is $0 \mathrm{~N}$.

Open contacts detween High Hydrogen Remote terminals TB2-21 ano TB2-2Z.

Trouble Beacon $X A-\star 63$ is . CY.

Open contacts between Cabinet irouic" a Remote terminals TB2-23 and TB2-24

A11 Indicating Lights EXCEPT the RESE? SAMPLER light are $\mathrm{N}$. 


\section{Rad 4 kran Red 4/ratab}

RQD 4164146

$22 k$

$4-116$

m. I.

$4-11-16$

$\frac{m+4}{4-\mu+6}$

$\frac{x+25}{4-4 x}$

axte

$4-1-8$

$\frac{m, N \pi x}{4-4+x}$

nate

$4 / / 16$

menes

2uxte

$4 \|-\pi$

tape

4-||-1
9.2.4.8.4 Release Alarm Test pushbutior.

9.2.4.8.5 Depress Alarm Reset pushbutton PB- $* 5$ :

followed by tine Horn Acknowledge pushbutton $\mathrm{PB}-\star 50$. Verify all inactive a' arms are reset.

9.2.4.8.6 Set fused switch FU-9 and FU-10 to the OPEN positior.

\subsubsection{Auto Sampler System}

9.2.4.9.1 Set fused switch FU-10 to the CLOSEO position.

9.2.4.9.2 Depress the Reset Sampler pushbutton PB*58 located inside the enclosure.

9.2.4.9.3 Depress the Grab Sample pushbutton PB-*59 located inside the enclosure. Verify the following conditions exist:

The Grab Sample pushbutton light PBL-*59 is illuminated.

The Reset Sample pushbutton light PBL-*58 is illuminated.

The Reset Sample light $\mathrm{YAL}-{ }^{*} 58$ is illuminated.

9.2.4.9.4 After five minutes verify that the Grab Sample pushbutton light PBL $* 59$ goes out and both the Reset Sample lights YAL-*5B and the Reset Sample pushbutton light PBL*58 remain on.

9.2.4.9.5 Depress the Grab Sample pushbutton PB-*59 and verify that the Grab Sample pushbutton light remains out.

9.2.4.9.6 Depress the Reset Sample pushbutton $\mathrm{PB}-\star 58$ and verify that both the Reset Sample light $\mathrm{YAL}-\star 58$ and the Reset Sample pushbutton light PBL-*58 go out.

9.2.4.9.7 Set fused switch FU-10 to the OPEN position. 
WHC-SD-WM-ATR-143

REV. 0

PAGE 22 OF 28

$4-1046$

man

$\frac{4-11-16}{m a s}$

9.2 .8
A $A$

\subsection{INTRIHSIC SAFETY CIRCUITS}

9.3.1 Verify INTRINSIC SAFEJY APPARATUS nameplates are located near intrinsic safety devices.

INTRINSIC SAFETY DEVICES:

$$
\begin{array}{lll}
\text { NE- } * 54 & \text { EB- } * 54 & \text { NIT-*52 } \\
\text { NE }-* 55 & \text { EB- } * 55 & \text { NIT-*55 }
\end{array}
$$


WHC-SD-WM-ATR-143

REV. 0

PAGE 23 OF 28

A A

\subsection{PNEUMATIC SYSTEMS}

This procedure will demonstrate that all process lines and devices function proper' $y$.

\subsection{PIPING}

\begin{tabular}{|c|c|c|}
\hline$m \cdot 3$ & 10.1 .1 & $\begin{array}{l}\text { Verify sample line heat trace from sample source } t= \\
\text { the cabinet is at least } 15 \text { feet in length. }\end{array}$ \\
\hline m.2. & 10.1 .2 & $\begin{array}{l}\text { Verify cal tbration line heat trace from calioration } \\
\text { gas tank to the cabinet is at least } 10 \text { feet in length. }\end{array}$ \\
\hline 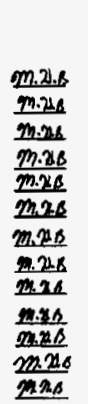 & 10.1 .3 & 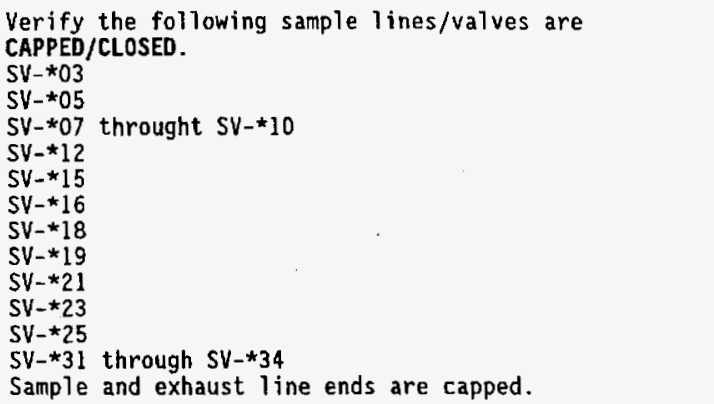 \\
\hline & 10.1 .4 & Verify the following sample line valves are OPEN \\
\hline 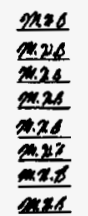 & & $\begin{array}{l}S V-\star 06 \\
S V-\star 11 \\
S V-\star 17 \\
S V-\star 20 \\
S V-\star 22 \\
S V-\star 24 \\
\text { FIV-*52 } \\
\text { FIV-*56 }\end{array}$ \\
\hline
\end{tabular}

\subsection{SAMPLE MAIN FLOW LOOP}

2uxs

all $4-1 / 26$

$$
\text { 10.2.1 Set fused switch FU-13 to the CLOSED position. }
$$


WHC-5D-WM-ATR-143

REV. 0

PAGE 24 OF 28

$m$ 10.2.2 Remove end caps from sample inlet and outlet lines Take care in not allowing foreign objects to enter lines.

$m a s$

2420

mo.2.s.

m.2.6

M.X.

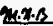

2non:

mas

10.2 .7
OPEN valves:

SY-*0J

$S V-* 05$

$\mathrm{SW}-* 16$

$S V-* 25$

10.2.4 Switch circuit oreaker CB-3 to tie CLOSED positior.

10.2.5 Adjust flow control valve SV- $* 24$ to nominally $5 " \mathrm{H}_{2} \mathrm{O}$ as indicated on $F[T-\star 5]$

10.2.6 Verify air is being extracted from the sample inlet line and air is being exhausted through the samp.e outlet line.

Verify the pressure differential indicator PDI-*5: indicates an upscale reading of less than $40 " \mathrm{H}_{2} \hat{\mathrm{O}}$.

10.3 AUTO GRAB SAMPLING LOOF

洜s

$\operatorname{2ns} A$

2425

$2 x+15$

222

$\sin 2 x$

2uns

nxos

$\geqslant 2 \pi 3$

all $4-11-96$
10.3.1 Set fused switch FU-10 to the CLOSED position.

10.3 .2

OPEN Va.ves:

$S V-* 15$

Gas Sample Assembly Valves

10.3 .3

Depress tine Grab Samp e pusibutton PB-*59. Veri that FIV- $\star 52$ indicates " $\mathrm{Cr}$.

10.3 .4

Adjust FIV- $\star 52$ to nominally $10 \%$ flow.

10.3 .5

CLOSE valves SV-*16 and SV-*25. Verify that FIV-*52 still indicates

10.3 .6

OPEN valves SV-*16 and SV-*25. CLOSE Valve SV-*15. Verify that $F I V-* 52$ indicates no flow.

10.3.7 Depress the Reset Sample pushbutton PE- $\$ 58$.

10.3.8 Set fused switch FU-10 to the OPEN pasitior. 
WHC-SO-WM-ATR-143

REV. 0

PAGE 25 OF 28

\subsection{CALIBRATION LOOP}

\begin{tabular}{|c|c|c|}
\hline $2 m 22$ & 10.4 .1 & Remove plug to atmosphere upstream of FLF- $\$ 55$. \\
\hline$\frac{\operatorname{man}}{2 \times 36}$ & 10.4 .2 & $\begin{array}{l}\text { OPEN valves: } \\
\text { SV-*18 } \\
S V-\star 31\end{array}$ \\
\hline 2uxt & 10.4 .3 & $\begin{array}{l}\text { Adjust to nominally } 2.0 \mathrm{cfh} \text { flow tinrougt, } \\
\text { FIV- } \star 5 E \text {. }\end{array}$ \\
\hline $2 x+8$ & 10.4 .4 & $\begin{array}{l}\text { CLOSE valves SV-* } 18 \text { and } S V-* 31 \text {. Verify that FIV-*56 } \\
\text { indicates zero flow. }\end{array}$ \\
\hline$\frac{x . x s}{2 m .2 . t 8}$ & 10.4 .5 & $\begin{array}{l}\text { OPER valves: } \\
\text { SV-*1S } \\
\text { SV-*3: }\end{array}$ \\
\hline 20218 & 10.4 .6 & 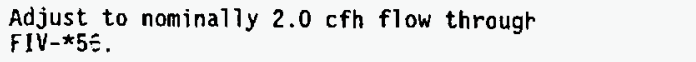 \\
\hline wase & 10.4 .7 & $\begin{array}{l}\text { CLOSE valves SV-*19 and SV-*31. Verify that FIV-*56 } \\
\text { indicates zero flo*. }\end{array}$ \\
\hline
\end{tabular}

10.5 ANALYTIC INSTRUMENT LOOP

2uas 10.5 .1 Open SV-*10, verify inward flow of gas.

2ry.B 10.5.2 Switch circuit breaker CB-3 to the OPEN position.

10.5.3 CLOSE the following sample line valves.

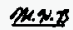

anx.x

mas

2328

$4 \times 5$

SV- 03

SV $-\star_{05}$

SV- 10

SV-* 16

SV $-* 25$

$\begin{array}{lll}\text { 10.5.4 } & \begin{array}{l}\text { Replace end caps on sample inlet and out let lines. } \\ \text { Replace plug upstream of FLT-*55. }\end{array} \\ \text { a/1 } 4-1 / .46 & 10.5 .5 & \text { Open the following circuit breakers and fuses: }\end{array}$ 
WHC-SD-WM-ATR-143

REV. $O$

PAGE 26 OF 28

A A

$2 m .2 B$

mine

M.n.
CB-1 throught $\mathrm{CB}-7$

FU-1 through FU-13

10.5 .6

De-energize power source to the Standard Hyaroger. Monitoring System. Refer to H-14-100297, Standard-C Hydrogen Monitoring System One Line \& Elementary Diagrams.

10.6 REVIEW

Check that all steps have been completed.

Mash of Buon 4-11-96. 
WHC-SD-WM-ATR-143

REV. :

PAGE 27 OF $2 \bar{E}$

A $A$

\subsection{DATA SHEETS}

\subsection{TEST DATA SHEETS}

The Test Data Sheets are used to document any procedure step requiring verification. A description of the data sheet format follows.

1. Date--Record the date the test is performed.

2. Title of Test--There are two tests being performed by this procedure, the Electrical Systems test and the Pneumatic systems test.

3. SHMS Unit Number--Record the unit number of the Standard Hydrogen Monitaring System.

4. Equipment Serial Number(s)--Record the serial numbers of any device used during the tests.

5. Test Performed By--Print the name of the craftsman performing the test.

6. Procedure Number--This column contains the test steps requiring verification.

7. Item--This column contains the item being verified, e.g., Pump, Air Conditioner, Heater, etc.

8. Value--This column contains the quantitative or qualitative measure of the item being verified, i.e. a line voltage may have a value of $120 \mathrm{~V}$, whereas a pump may have a value of ON or OFF.

9. Range--This column indicates the anticipated value of the item being measured.

10. Accept/Reject--Indicate whether the value obtained is acceptable in comparison with the Range.

11. Comment--If the value is rejected, give a justification for denial.

Test Data Sheets are included in Appendix A.

\subsection{TEST EXCEPTION SHEET}

Exception Data Sheets are used to document exceptions to the test procedure. Actions taken regarding disposition are noted on the exception sheet. Typical dispositions are: 
1. Test approved with exception (i.e. rerun of the acceptance test

unnecessary)

2. Entire acceptance test to be repeated after the discrepancy ias jeen corrected.

3. Acceptance Test Procedure step(s) affected to be repeated after tine discrepancy ias been correctec.

Test Exception Sieets are included in Appendix E.

\subsection{TEST LOG SHEET}

Test Log Sineets are used to document test start and stop times ars is document any other notes concerning the execution of the Acceptance est Procedure.

Test Log Sheets are included in Appendix 0. 
WHC-SD-WM-ATR-143

REV. $O$

PAGE Al OF A7

APPENDIX A: TEST DATA SHEETS

A $A$

TEST DATA SHE::

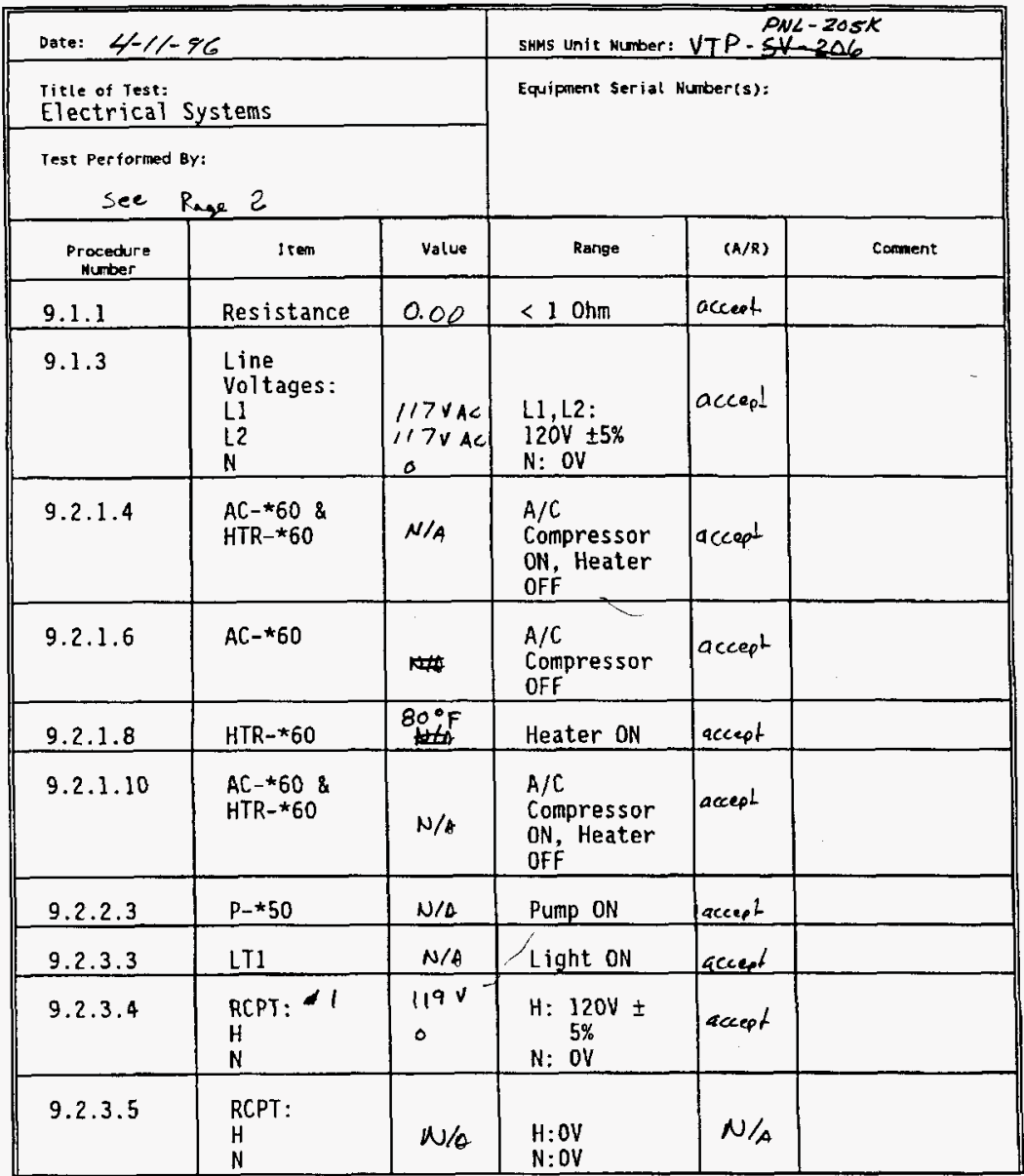


WHC-SD-WM-ATR-143

REV. 0

PAGE A2 OF A7

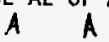

TEST DATA SHEE:

mat) 4 an-16

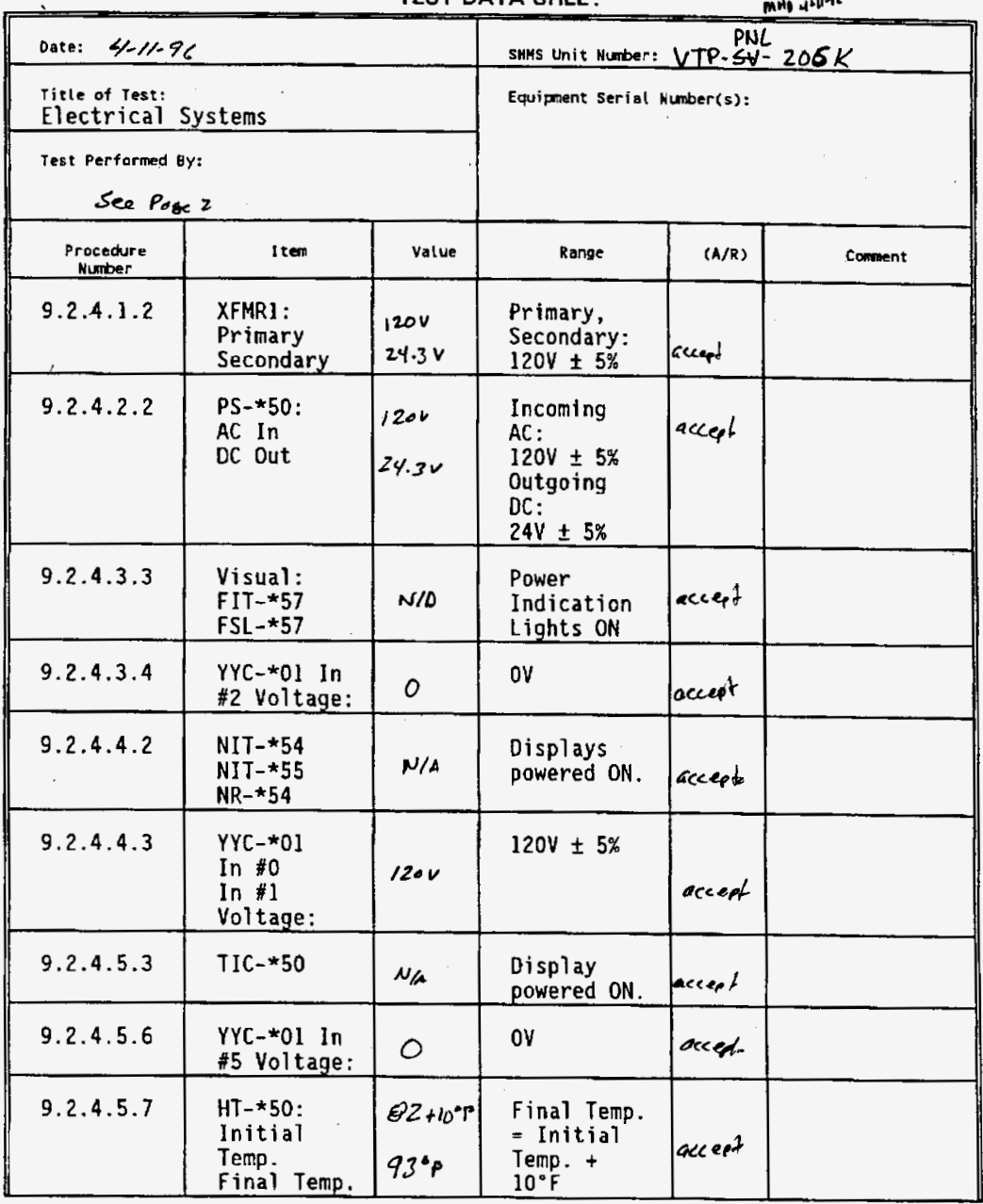


WHC-SD-WM-ATR-143

REV. 0

PAGE A3 OF A7

A $A$

TEST DATA SHEET

\begin{tabular}{|c|c|c|c|c|c|}
\hline \multicolumn{3}{|c|}{ Date: $\quad 4-11-96$} & \multicolumn{3}{|c|}{ SHMS Unit Humber: VIP-PNL-205K } \\
\hline \multicolumn{3}{|c|}{$\begin{array}{l}\text { Title of Test: } \\
\text { Electrical Systems }\end{array}$} & \multirow{3}{*}{\multicolumn{2}{|c|}{$\begin{array}{l}\text { Equipment Serial Nunber(s): } \\
\qquad N / A\end{array}$}} & \\
\hline \multirow{2}{*}{\multicolumn{3}{|c|}{$\begin{array}{l}\text { Test Performed By: } \\
\text { See Pay } 2\end{array}$}} & & & \\
\hline & & & & & \\
\hline $\begin{array}{l}\text { Procedure } \\
\text { Number }\end{array}$ & Item & value & Renge & (A/R) & Corment \\
\hline 9.2 .4 .5 .9 & $\begin{array}{l}Y Y C-\star 01 \text { In } \\
\$ 5 \text { Voltage: }\end{array}$ & $120 \mathrm{~V}$ & $120 \mathrm{~V} \pm 5 \%$ & acces & \\
\hline 9.2 .4 .6 .2 & $T I C-\star 56$ & $N / A$ & $\begin{array}{l}\text { Display } \\
\text { powered ON. }\end{array}$ & ascest & \\
\hline 9.2 .4 .6 .5 & $\begin{array}{l}\text { YYC-*01 In } \\
\# 4 \text { Voltage: }\end{array}$ & 0 & ov & aeceet & \\
\hline 9.2 .4 .6 .6 & $\begin{array}{l}\text { HT-*56: } \\
\text { Initial } \\
\text { Temp. } \\
\text { Final Temp. }\end{array}$ & $\begin{array}{l}60 \% \\
+10^{\circ} \\
=710 \mathrm{~F} \\
\end{array}$ & $\begin{array}{l}\text { Final Temp. } \\
=\text { Initial } \\
\text { Temp }+10^{\circ} \mathrm{F}\end{array}$ & accent & \\
\hline 9.2 .4 .6 .8 & $\begin{array}{l}\text { YYC-*01 In } \\
\# 4 \text { Voltage: }\end{array}$ & $120 \mathrm{~V}$ & $120 \mathrm{~V} \pm 5 \%$ & aucest & \\
\hline 9.2 .4 .7 .2 & TIS $-\star 62$ & $N / D$ & $\begin{array}{l}\text { Display } \\
\text { powered ON. }\end{array}$ & beepl & \\
\hline 9.2 .4 .7 .5 & $\begin{array}{l}\text { YYC-*01 in } \\
\# 3 \text { Voltage: }\end{array}$ & 1210 & $120 \mathrm{~V} \pm 5 \%$ & accerl & \\
\hline 9.2 .4 .7 .7 & $\begin{array}{l}Y Y C-{ }^{*} 01 \text { In } \\
\# 3 \text { Voltage: }\end{array}$ & 0 & ov & accent & \\
\hline 9.2 .4 .7 .9 & $\begin{array}{l}Y Y C-{ }^{*} 01 \text { In } \\
\# 3 \text { Voltage: }\end{array}$ & 120 & $120 V \pm 5 \%$ & aceent & \\
\hline 9.2 .4 .7 .11 & $\begin{array}{l}\text { YYC-*01 In } \\
\# 3 \text { Voltage: }\end{array}$ & 0 & ov & acced & \\
\hline
\end{tabular}


WHC-SD-WM-ATR-143

REV. 0

PAGE A4 OF AT

A $A$

TEST DATA SHEET

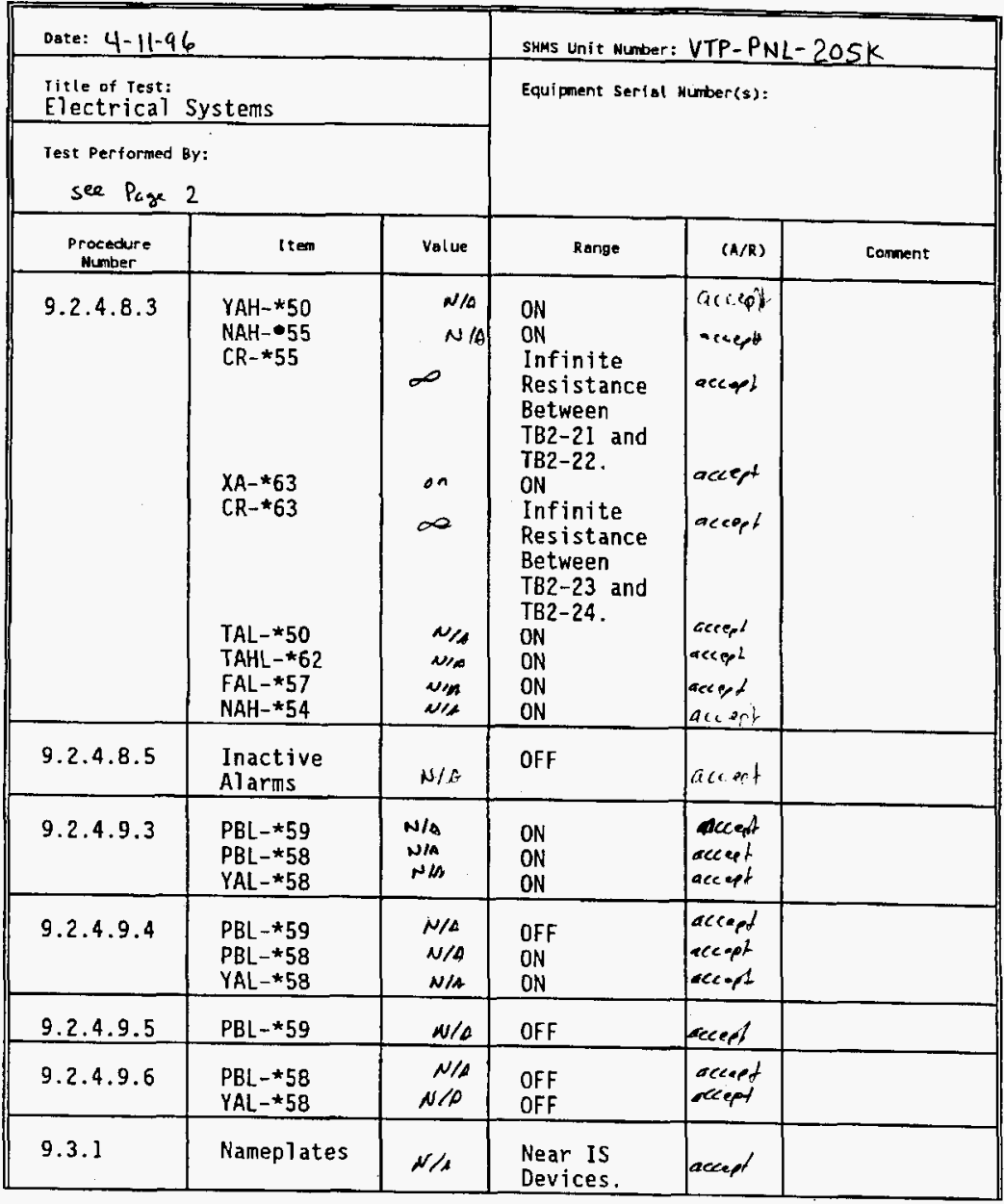




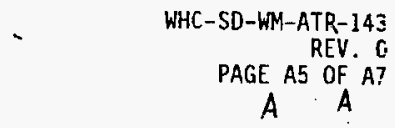

\section{TEST DATA SHEET}

\begin{tabular}{|c|c|c|c|c|c|}
\hline \multicolumn{3}{|c|}{ Date: $4-11-96$} & \multicolumn{3}{|c|}{ SHMS Unit Mumber: VTP-PNL $-205 K$} \\
\hline \multicolumn{3}{|c|}{$\begin{array}{l}\text { Title of Test: } \\
\text { Electrical Systems }\end{array}$} & \multirow{2}{*}{\multicolumn{3}{|c|}{ Equipment Serial Number(s): }} \\
\hline \multicolumn{3}{|c|}{ Test Performed By: } & & & \\
\hline $\begin{array}{c}\text { Procedure } \\
\text { Mulmoter } \\
\end{array}$ & Item & value & Range & $(A / R)$ & Comment \\
\hline 9.3 .2 & Wiring & $N / A$ & $\begin{array}{l}\text { Proper } \\
\text { Labeling. }\end{array}$ & accers & \\
\hline 9.3 .3 & Resistance & 0.0 & $<10 \mathrm{hm}$ & accept & \\
\hline
\end{tabular}

Test witnesses:

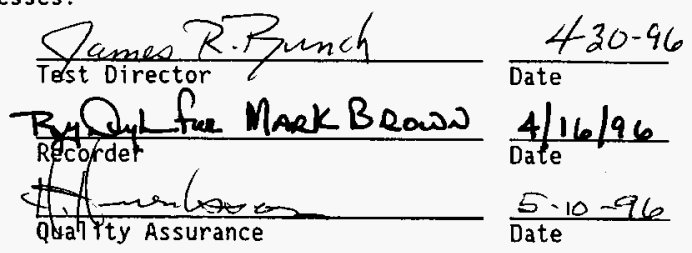


WHC-SD-WHY-ATR-: 43

REV. 0

PAGE AG OF AT

TEST DATA SHEET

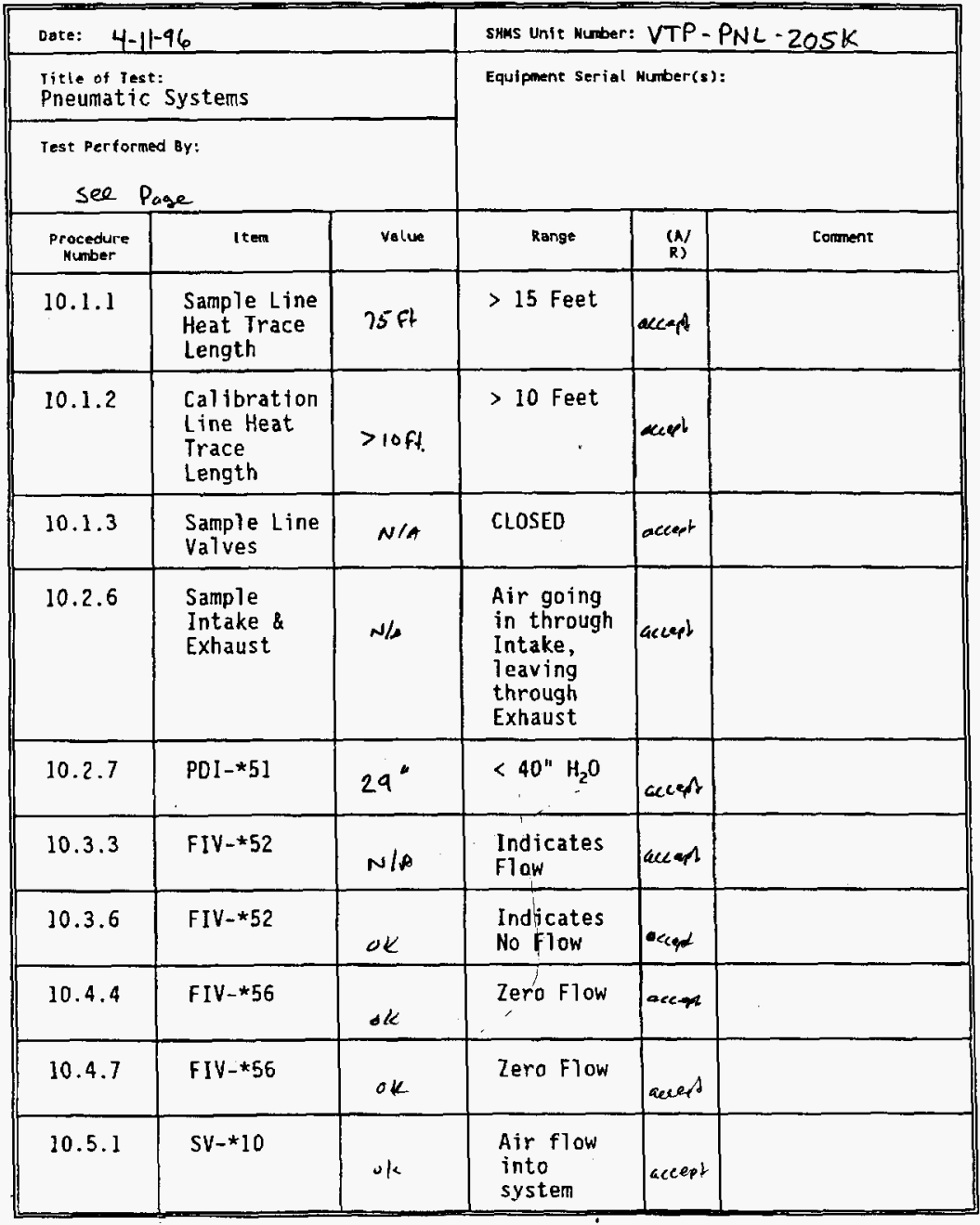


WHC-SD-WM-ATP-143

REV. 0

PAGE A7 OF AT

Test Witnesses:

$A$ A

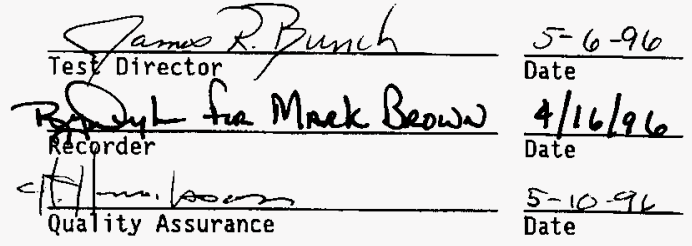


WHC-SD-WM-ATP.-143

REV. 0

PAGE BI OF BI

APPENDIX B: TEST EXCEPTION SHEETS

$A \quad A$

TEST EXCEPTION SHEET

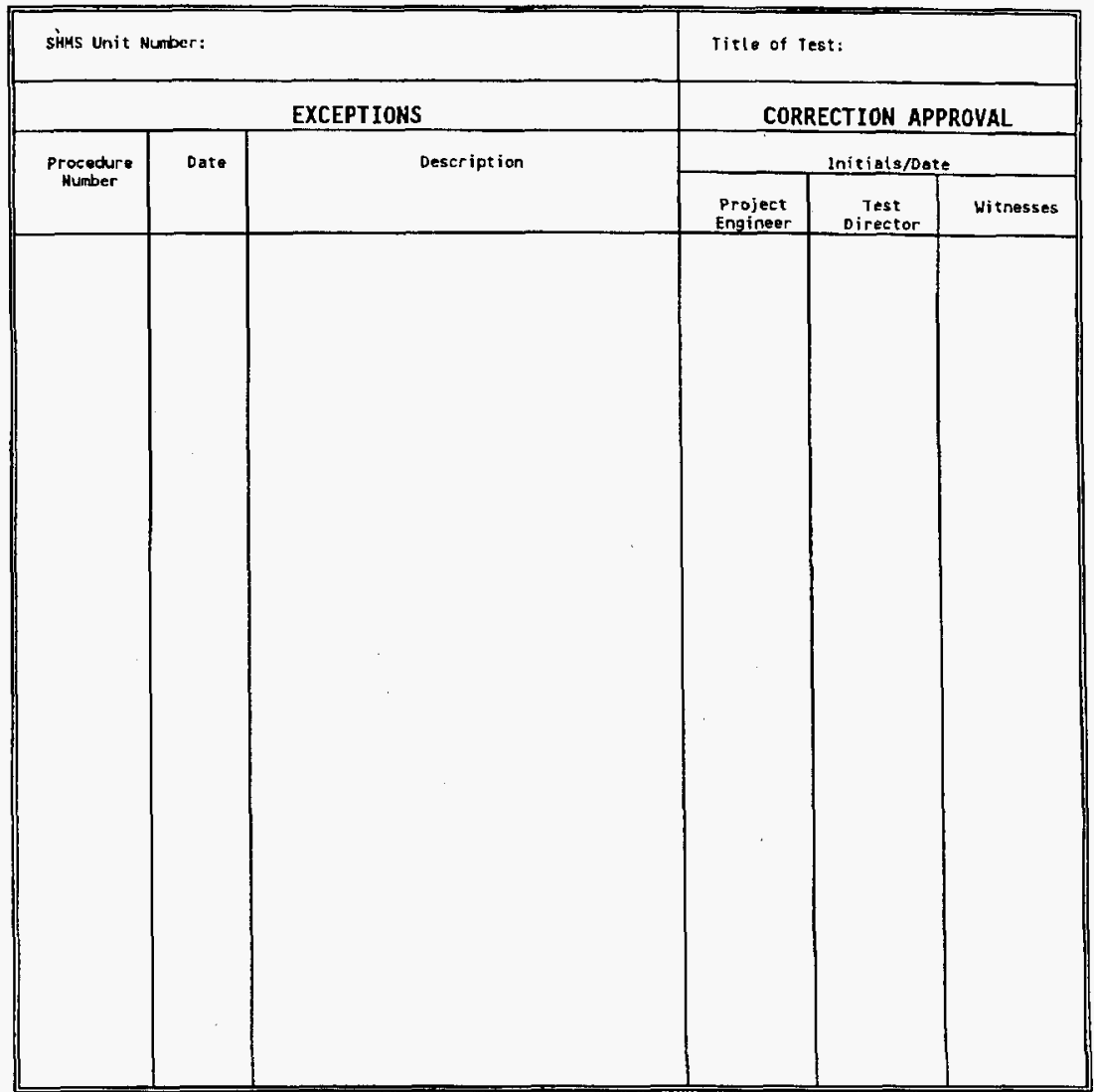

IEST APPROVED WITH EXCEPTIONS

WHC Project Engineer

Date

Recorder

Date

Witness

Date 


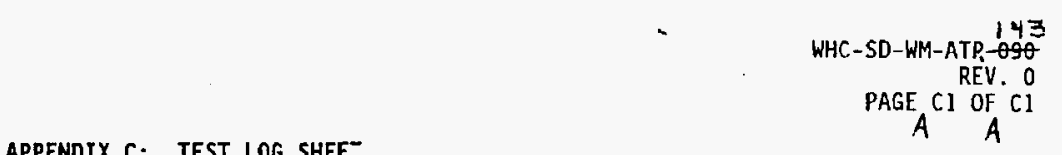

APPENDIX C: TEST LOG SHEE-

TEST LOE

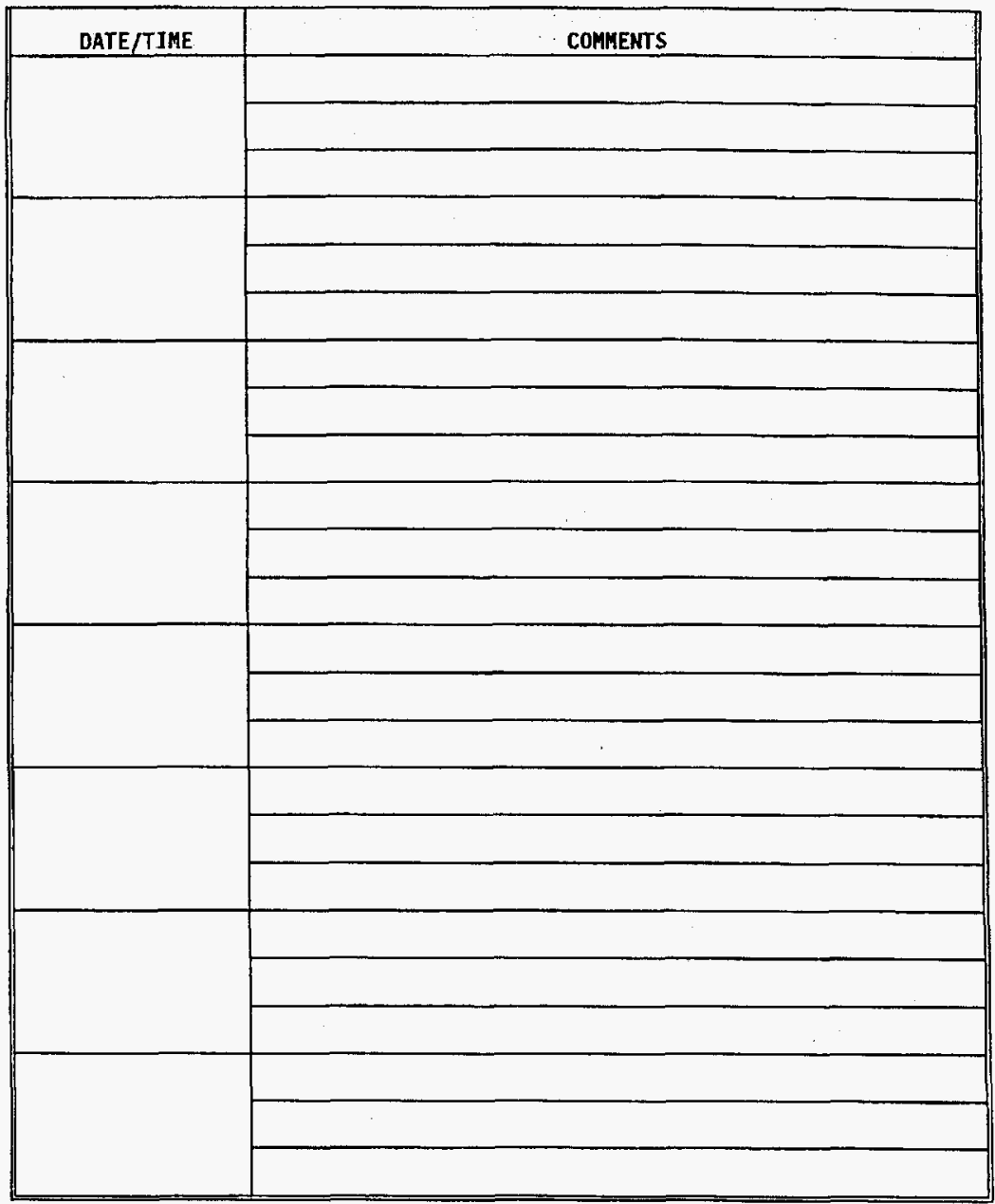


WHC-SD-WM-ATR-143

Rev. 0

PageBI

APPENDIX B (241-AN EXHAUSTER STACK) 
TEST EXECUTION SHEET

\begin{tabular}{|c|}
\hline $\begin{array}{l}\text { Date: } 5 / 10 / 96 \\
\text { SHMS Unit VTP-PNL tO5K } \\
\text { Wumber: } V \text { Document Number: }\end{array}$ \\
\hline TEST PERSONNEL \\
\hline 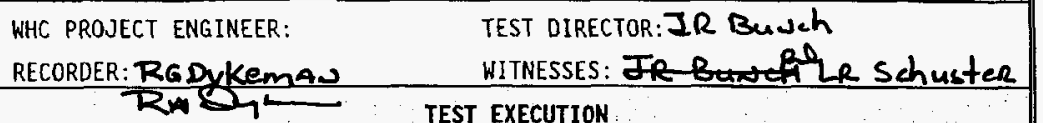 \\
\hline 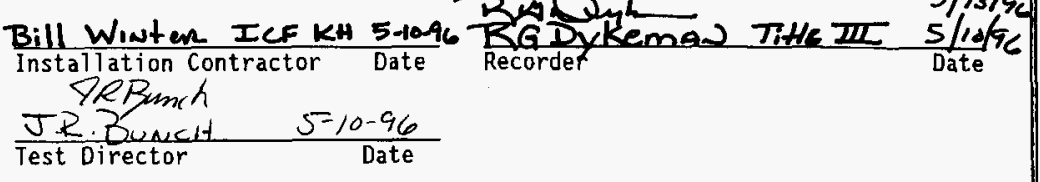 \\
\hline TEST WITNESS \\
\hline Witness $O$ Date Witness \\
\hline TEST ACCEPTANCE \\
\hline $\begin{array}{l}\text { Kaiser Engineers Hanford } \\
\text { Without } \\
\text { Field engineering }\end{array}$ \\
\hline TEST APPROVAL AND ACCEPTANCE \\
\hline 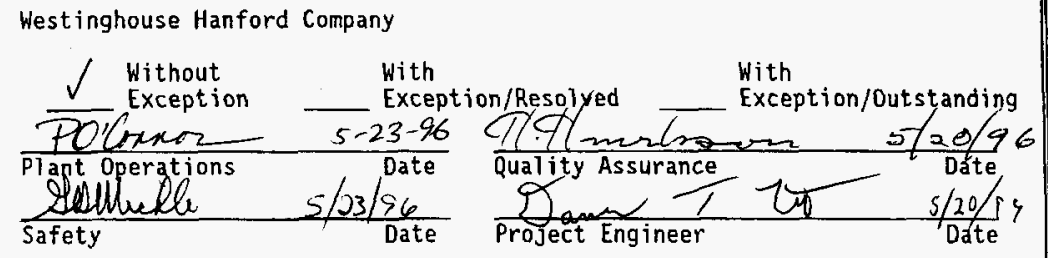 \\
\hline
\end{tabular}


WHC-SD-WM-ATR-143

REV. 0

PAGEB 3 OFB 28

TABLE OF CONTENTS

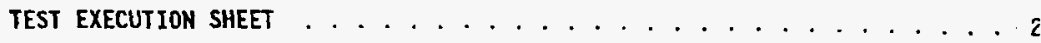

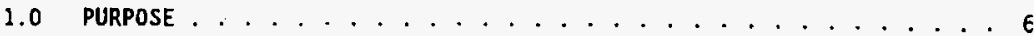

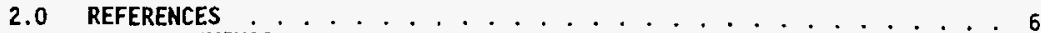

2.1 DRANINGS ....................... 6

2.2 PROCEDURES ......................... . . . . . 7

3.0 RESPONSIBILITIES . . . . . . . . . . . . . . . . 7

3.1 WHC PROJECT ENGINEER ................. 7

3.2 TEST DIRECTOR . . . . . . . . . . . . . . . . . . . . . . . 8

3.3 WITNESSES . . . . . . . . . . . . . . . . . . . 9

3.4 RECORDER . . . . . . . . . . . . . . . . 9

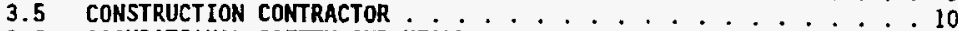

3.6 OCCUPATIONAL SAFETY AND HEALTH ................ 11

4.0 ACCEPTANCE TEST PROCEDURe Change CONTRO_ . . . . . . . . . . . 11

5.0 TEST EXECUTION . . . . . . . . . . . . . . . . . 11

5.1 WITHOUT EXCEPTION . . . . . . . . . . . . . . . . . . 12

5.2 WITH EXCEPTION/RESOLVED . . . . . . . . . . . . . . . . 12

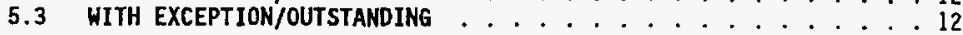

6.0 RECORDING AHD RESOLVING EXCEPTIONS ................. 12

6.1 GENERAL . . . . . . . . . . . . . . . . . . . . 13

6.2 RECORDING . . . . . . . . . . . . . . . . . 13

6.3 RETEST/RESOLUTION . . . . . . . . . . . . . . 13

6.4 APPROVAL AND ACCEPTANCE ................... . . . . . 13

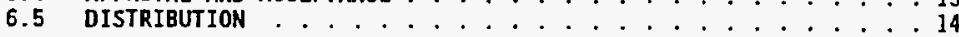

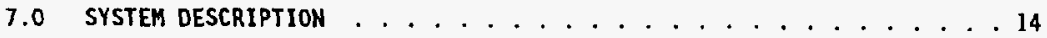

8.0 TEST CONDITIONS AND EQUIPMENT REQUIRED . . . . . . . . . . . . . . 14

8.1 TEST CONDITIONS ....................... . . . 14

8.2 EQUIPMENT REQUIRED . . . . . . . . . . . . . . . . . 16

9.0 ELECTRICAL SYSTEMS

9.1 SHMS POWER SUPPLY . . . . . . . . . . . . . . . . . 17

9.2 ELECTRICAL DEVICES

9.2.1 Heating and Air Conditioning . . . . . . . . . . . 17

9.2 .2 Sample Pump . . . . . . . . . . . . . . . . 18

9.2.3 Panel Power Supply . . . . . . . . . . . . . . . . 19

9.2 .4 Cabinet Instrumentation . . . . . . . . . . . . . . 19

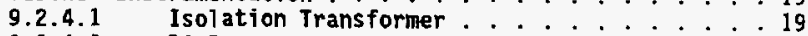

9.2.4.2 DC Power ................. 19

9.2.4.3 Flow Alarm System ............ 20 
WHC-SD-WM-ATR-143

REV. :

$\mathrm{PAGE}_{B^{4}} \mathrm{OF}_{B} 2 E$

9.2.4.4 Hyorogen Sensors ............. 20

9.2.4.5 Sample Gas Heat Trace ............ 21

9.2.4.6 Calibration Gas Heat Trace . . . . . . 22

9.2.4.7 Cabinet Temperature ........... 23

9.2.4.8 Alarm Systems.............. . . 24

9.2.4.9 Auto Sampler System . . . . . . . . . 25

9.3 INTRINSIC SAFETY CIRCUITS .................. . 27

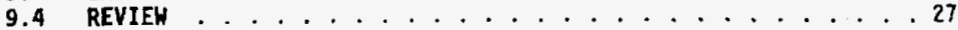

10.0 PNeUMatic SYSTEMS ........................ . . $2 E$

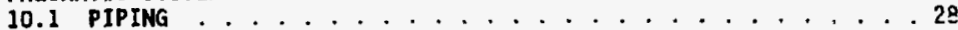

10.2 SAMPLE MAIN floW LOOP . . . . . . . . . . . . . . . . . . 29

10.3 AUTO GRAB SAMPLING LOOP . . . . . . . . . . . . . . 29

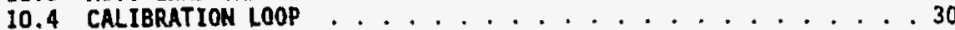

10.5 ANALYTIC INSTRUMENT LOOP .................. 31

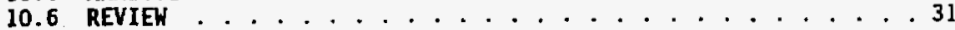

11.0 DATA SHEETS . . . . . . . . . . . . . . . . . . . . 33

11.1 TEST DATA SHEETS . . . . . . . . . . . . . . . . . 33

11.2 TEST EXCEPTION SHEE: ........................... 34

11.3 TEST LOG SHEET . . . . . . . . . . . . . . . . . . 34

APPENDIX A: TEST DATA SHEETS ..................... . I

APPENDIX B: TEST EXCEPTION SHEETS . . . . . . . . . . . . . . . 1

APPENDIX C: TEST LOG SHEET . . . . . . . . . . . . . . . . I 
WHC-SD-WM-ATR-143

REV. $\hat{\vdots}$

PAGE $_{B} 5 \mathrm{OF}_{B} 2 \Omega$

\section{STANDARD-D HYDROGEN MONITORING SYSTEM \\ ACCEPTANCE TEST PROCEDURE}

\subsection{PURPOSE}

The purpose of this document is to demonstrate that the Standard-D Hydrogen Monitoring System is constructed as intended by design. This document does not include testing of ammonia or organic sampling equipment. Additions of this type of equipment will require a seperate test document.

\subsection{REFERENCES}

\subsection{DRAWINGS}

- H-14-100295, Standard-D Hydrogen Monitoring System Piping \& Instrumentation Diagram.

- H-14-100296, Standard-D Hydrogen Monitoring System Equipment Arrabgement.

- H-14-100297, Standard-D Hydrogen Monitoring System One-Line, Elementary Diagrams.

- H-14-100298, Standard-D Hydrogen Monitoring System Cabinet Assembly.

- H-14-100299, Standard-0 Hydrogen Monitoring System Wiring Diagram.

- H-14-100300, Standard-D Hydrogen Monitoring Systen Interior Panels a Brackets.

- H-14-100301, Standard-D Hydrogen Monitoring System Cabinet Modifications.

- H-14-100302, Standard-D Hydrogen Monitoring System Loop Diagrams.

- H-14-100303, Standard-D Hydrogen Monitoring System PLC Ladder Diagram.

- H-14-100304, Standard-D Hydrogen Monitoring System Instrument Panel Assembly.

- H-2-818214 Standard-B Hydrogen Monitoring System Gas Bottle Rack

- H-2-818220, Standard-B Hydrogen Monitoring System Sample Pump Stand Assembly. 
WHC-SD-WM-ATR-14乏

REV. C

PAGE $_{B} 6 \underset{B}{O F_{B}} 28$

\section{、 2.2 PROCEDURES}

- WHC-CM-4-3, Volume 1, Program E-2, Electrical Safety Practices.

\subsection{RESPONSIBILITIES}

Each company or organization participating in the conduct of this ATF will designate personnel to assume the responsibilities and duties as defired herein for their respective roles. The names of these designees shall be provided to the Recorder for listing on the Recorder's copy of the Test Execution Sheet prior to the performance of any part of this ATf.

\subsection{WHC PROJECT ENGINEER}

3.1.1 Designate a Test Director.

3.1.2 Coordinate testing with facility management.

3.1.3 Act as liaison between the participants in acceptance testir: $=$

3.1.4 Distribute the approved testing scheduie as soon as possible, but at least two days prior to testing.

3.1.5 Ensure field testing and inspection has beer completed.

3.1.6 Scheduie and conduct a pre-ATP meeting with tes: participants prior to start of testing.

3.1.7 Notify the persons performing and witnessing the test prior to the start of testing.

3.1.8 Notify all concerned parties when a change is made in the testing schedu'e.

3.1.9 Sign Test Execution Sheet when ATP is approved and accepted.

3.1.10 Take necessary action to clear exceptions to the ATP.

3.1.11 Sign Exception Sheet when exception has been resolved.

3.1.12 Provide a distribution list for the approved and accepted A'F. 
WHC-SO-WM-ATP-143

REV. $\mathrm{C}$

PAGE 7 OF 28

$8 B$

\subsection{TEST DIRECTOR}

3.2.1 Coordinate all acceptance testing.

3.2.2 Confirm that field testing and inspection of the system or portion of the system to be tested has beer. completed.

3.2.3 Stop any test which may cause damage to the system until the test procedure has been revisea.

3.2.4 Approve field cianges to the ATP.

3.2.5 Obtain revisions to the ATP, as necessary, to compiy with authorized field changes or to accommodate existing field conditions.

3.2.6 Evaluate recorded data, discrepancies, and exceptions.

3.2.7 Obtain from the WHC Project Engineer, any information or changes necessary to clear or resolve objections.

3.2.8 Sign Test Execution Sheet when ATP has been performed.

3.2.9 Sign Test Exception Sheet wien retest has been executed and acceptec.

3.2.10 Obtain required signatures on the ATP Master prior to reproduction and distribution.

3.3 WITNESSES (Provided by Participating Organizations)

3.3.1 Witness the tests.

3.3.2 Evaluate results of testing.

3.3.3 Assist the Test Director winen requestec.

3.3.4 Sign Test Exception Sneet as a Wizness.

3.3.5 Sign Test Exception Sheet as a Witness when retest has been executed and accepted.

3.4 RECORDER (Appointed by Test Director, Provided by KEH if KEH installed equipment)

3.4.1 Record names of all designated personnel on Recorder's copy of ATP prior to start of testing. 


\section{4 .2}

3.4 .4

$3,4.7$

3.4 .8

3.4 .9

WHC-SD-WM-ATR-143
REV.C
PAGE 8 OF 28
$B$ Observe tests, recora test data and maintain test
og.

Sign the Test Exception Sheet as the Recorder.

Initial and date every test step on the Recorder's copy as it is completed, next to the step number or or a table, when provided. On tables where there is not room for both the initial and the daie, aate may be entered in space provided at bottom of columr.

Record authorized field changes to the ATF.

Record exceptions and test steps that are not performed on the Test Exception Sheet. have tine information transferred in ink or typed to tine Master Exception Sneet(s). Additional Exception Sneets are to be added as neeaec.

Orally notify the Test Director at time the objectior: is made.

Assign page number to Data Sheets and Exceptior Sheets, after ATP is complete. Record Page numbers for these items and mace corrections, as necessary, tc page numbers shown for these pages in the inoex.

Transfer the final test results with Recorder's signature and dates for each step to the Master in ink or type. Submit the completed Master to the Test Director for approval slgnatures and distrijution. Retain the Recorder's copy and copy of the Master in the field project files. If the cabinet is installed and tested oy WHC, a seperate Master test copy is not required, the Recorder s copy may be used.

\subsection{CONSTRUCTION CONTRACTOR}

3.5.1 Organize and perform this acceptance test under coordination of the Test Director.

3.5.2 Confirm that all equipment required for performing this test (as listed in Section 8.2 ) will be available at start of testing.

3.5.3 Provide equipment required for performing this acceptance iest, which has not been designatec as being provided by otiners.

3.5.4 Request in writing from the Project Engineer those services, materials, or equipment that have beer: 
WHC-SD-WM-ATR-143

REV. C

PAGE 9 OF 28

B B

designated as being supplied by the Department of Energy (DOE) or others.

\subsection{OCCUPATIONAL SAFETY AND HEALTH}

Individuals shall carry out their assigned work in a safe manner to protect themselves, others, and the equipment from undue hazards and to prevent damage to property and environment. Facility line managers shall assure the safety of all activities within their areas to prevent injury, property damage, or interruption of operation. Performance of test activities shall always include safety and health aspects as delineated in the Operations Manuals and as directed by the WHC Project Engineer. Any hazard identified during the performance of the ATP shall be reported to the manager of Waste Tank Safety Assurance.

\subsection{ACCEPTANCE TEST PROCEDURE CHANGE CONTROL}

Acceptance testing is to be conducted in accordance with the steps and requirements specified in this procedure. Any required changes must be authorized in accordance with Section 3.2 and with approved change control procedures.

\subsection{TEST EXECUTION}

The acceptance test procedures detailed in Sections 9.0 and 10.0 shall be performed in sequential steps starting with Section 9.0. As required by Section 3.4, the Recorder will initial and date every test step in the space provided on the Recorder's copy of the ATP as each step is completed. Any step that requires verification must also be recorded on the Test Data Sheet.

\subsection{WITHOUT EXCEPTION}

5.1.1 Check applicable space on Test Execution Sheet to show that the ATP has been performed and no exceptions have been recorded.

5.1.2 Sign and date Test Execution Sheet in the spaces provided.

5.1.3 Distribute requisite copies and send master of ATP to the client. 
WHC-SD-WM-ATR-143

REV. $\vartheta$

PAGE $_{B} 10$ OF 28

\subsection{HITH EXCEPTION/RESOLVEL}

5.2.1 Check applicable space on Test Execution Sheet to show that the ATP has been performed witn exceptiors recorded and resolvec.

5.2.2 Sign and date Test Execution Sheet in the spaces provided.

5.2.3 Distribute requisite copies and send master of ATP to the clier:-

\subsection{WITH EXCEPTION/OUTSTAYDING}

5.3.1 Check applicable space on Test Execution Sheet to show that the ATP has been performed with exceptions recorded, part or all of winich are presently outstanding, unresolved.

5.3.2 Sign and date Test Execution Sheet in the spaces provided.

5.3.3 Distribute requisite copies and send master of ATP to the clier:.

\subsection{RECORDING AND RESOLVING EXCEPTIONS}

\subsection{GENERAL}

Exceptions to the ATP are sequentially numbered and recorded or: individual Exception Sheets. Tnis enables case-by-case resolution, recordins, approval, and distribution of each exceptior.

\subsection{RECORDING}
6.2 .1
Number each excepition sequentially as it occurs anc record it on an Exception Sriee:
6.2 .2
Enter name and organization of objecting party for each exceptior.
6.2.3 Enter planned action to resolve each exception when such aetermination is made. 
WhC-SD-WM-ATR-143

REV. C

PAGE 11 OF 28

B B

\subsection{RETEST/RESOLUTION}

6.3.1 Record the action taken to resolve each exceptior.

Action taken may not be the same as planned action.

6.3.2 When action taken results in an acceptable retes: sign and date Retest Execution and Acceptance sectior. of the Exception Sheet.

6.3.3 When action taken does not involve an acceptable retest, strike out the Retest Execution and Acceptance section of the Exception Sheet. Resolve exception as shown under 6.4 below.

\subsection{APPROVAL AND ACCEPTANCE}

\section{4 .1}

The Project Engineer provides final approval and acceptance of exception by checking one of the following on Exception Sheet:

- Retest Approved and Accepted: Applicable when Retest Execution and Acceptance section is completed.

- Exception Accepted-As-Is: Requires detalled explanation.

- Other: Requires detailed explanation.

6.4.2 The Project Engineer signs and dates the Exception Sheet and obtains other internal approval, if required.

\subsection{DISTRIBUTION}

Distribute requisite copies of completed Exception Sheets to the client.

\subsection{SYSTEM DESCRIPTION}

The primary function of the Standard Hydrogen Monitoring System is to monitor specifically for hydrogen in the waste tank atmosphere which may also contain (but not be limited to) unknown quantities of air, nitrous oxide, ammonia, water vapor, carbon dioxide, carbon monoxide, and other gaseous constituents. 
- The SHMS will consist of hydrogen specific monitors, a grab sampler ic collect samples for laboratory analysis, and the gas sample collection system necessary to support the operation of the instrumentation. This system will be located in a cabinet placed at the tank of interest.

\subsection{TEST CONDITIONS AND EQUIPMENT REQUIRED}

\subsection{TEST CONDITIONS} testing.

The following conditions shall exist at the start of tine acceptance

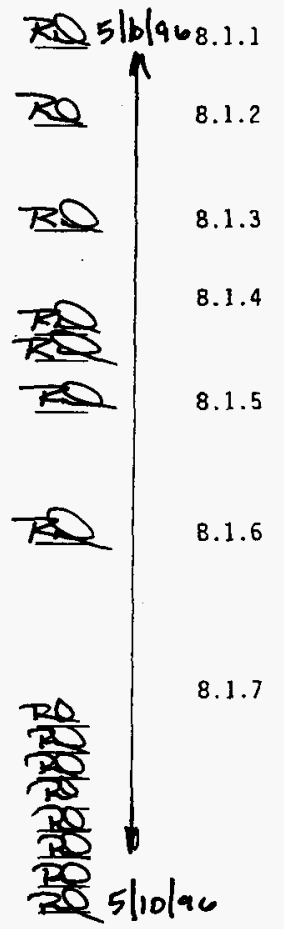

Systems being tested have been inspected for workmanship and for compliance with design.

Continuity and megger tests have been performed or portions of the electrical and instrument systems being tested, as required.

Leak tests on the pneumatic systems have bee? performed.

The following circuit breakers and fuses are open CB-I throught CB-7

FU-1 through FU-13

All test instruments have a currently valid calibration stamp attached that indicates a calibration traceable to the National Institute of Standards and Technology.

Personnel responsible for directing and witnessing the performance of the tests described in this ATP have read and understand appropriate certified vendcr information (CVI) pertaining to the operation of the equipment to be tested.

The following sample lines/valves are CAPPED/CLOSED, SV-*03

$5 V-\star_{05}$

SV-*07 throught SV-*10

SV $-\star 12$

SV-*15

SV-*]6

$5 V-* 18$

SV-*1G 
WHC-SD-WH-ATR-143

REV. 0

PAGE 13 OF $2 E$

B

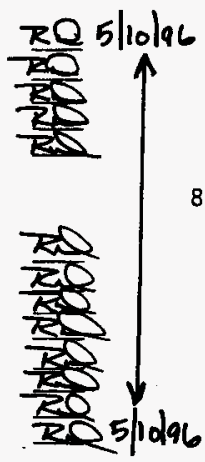

$\mathrm{SW}-{ }^{*} \mathrm{C}:$

$S V-* 23$

$S V-\star 25$

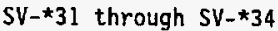

Sample and exhaust line ends are cappec.

8.1.8 The following sample line valves are OPEN
SV-*06
SV-*11
SV-* 17
SV-*20
SV $-\star 22$
SV-*24
FIV $-* 52$
FIV $-* 56$

Check that all prerequisites have been met.

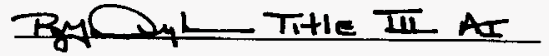

\section{B.2 EQUIPMENT REQUIRED}

The Contractor shall supply all test equipment unless otherwise noted. 
WHC-SD-WM-ATR-143

REV. 0

PAGE 14 OF 28

B B

\subsection{ELECTRICAL SYSTEMS}

This procedure will demonstrate that all electrical aevices function properly.

\subsection{SHMS POWER SUPPLY}

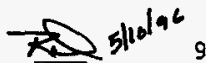

9.1.1 Verify resistance Detween system ground and cabine: enclosure is less than one (i) onr..

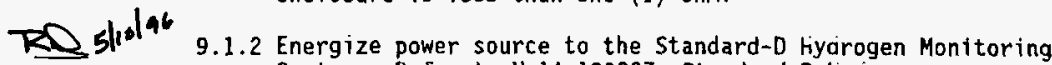
System. Refer to H-14-100297, Standard-D hyorogen

Monitoring System 0ne Line \& Elementary Diagrams.

2.1.3 Verify line voltages, L1, L2, and $N$, at terminal block.

\subsection{ELECTRICAL DEVICES}

\subsubsection{Heating and Air Conditioning}

FO $5-10.96 \quad 9.2 .1 .1$

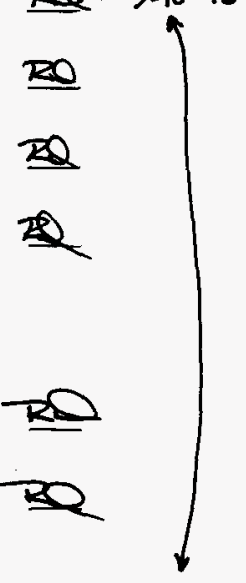

9.2.1.1 Adjust Air Conditioner $(A C-\star 60)$ temperature control to a value below ambient temperature.

9.2.1.2 Adjust Heater (HTR-*60) temperature control to a value below ambient temperature.

9.2.1.3 Switch circuit breaker CB-1 to the CLOSED position.

9.2.1.4 Verify Air Conditioner is operating and Heater is off.

NOTE: If ambient temperature is below Air Conditioner's minimum setting, a heat gun may be used to heat the $A / C$ 's temperature probe.

9.2.1.5 Adjust Air Conditioner temperature control to a value above ambient temperature.

9.2.1.6 Verify Air Conditioner compressor turns OFF. NOTE: Air Conditioner fan may stili operate. 
WHC-SD-WM-ATR-143

REV. -

PAGE 15 OF 28

B $B$

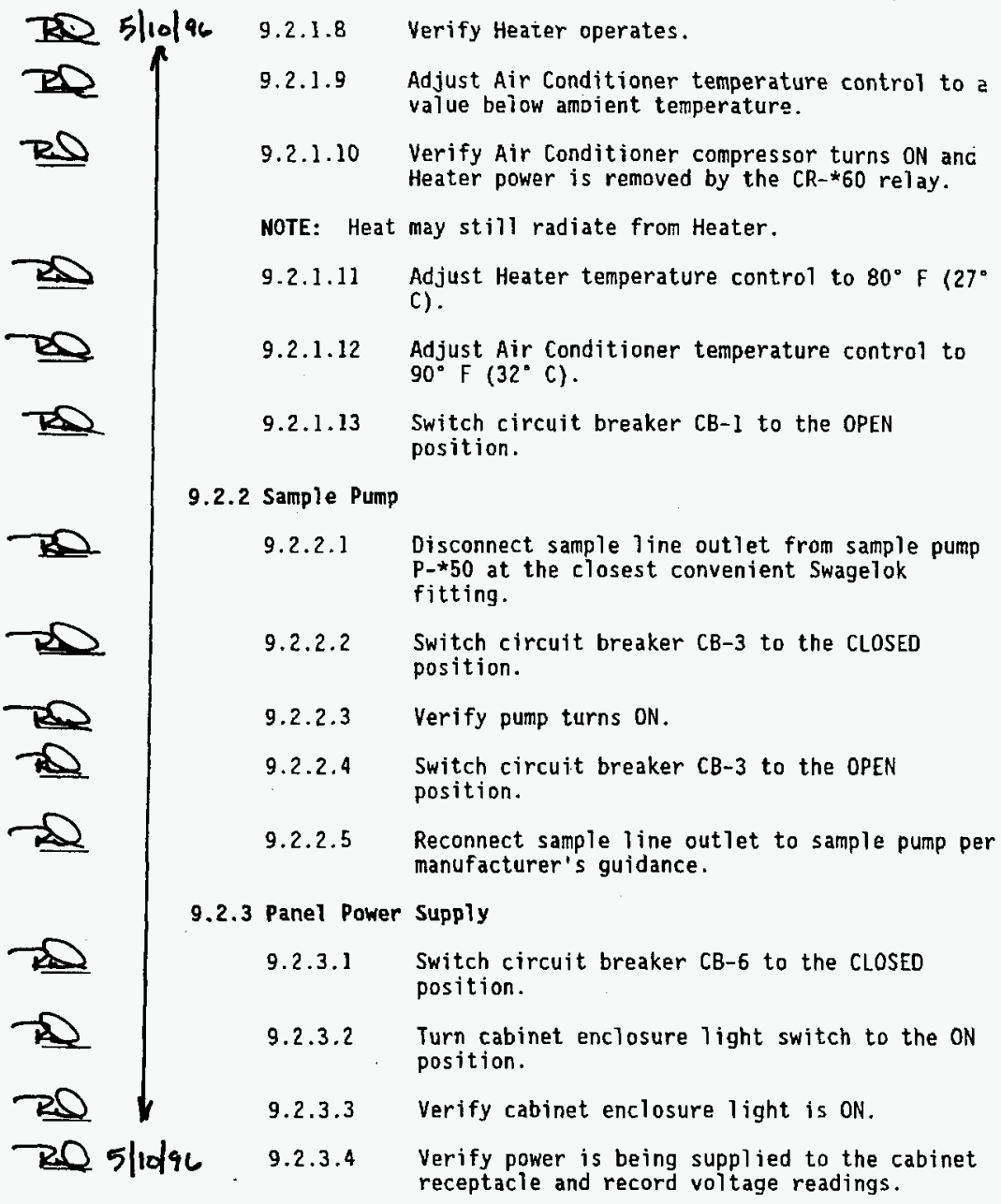


WHC-SD-WH-ATR-143

REV. 0

PAGE 16 OF 828

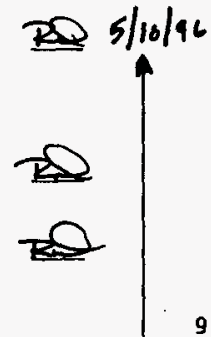

9.2.3.5 Test GFI capability jy depressing "TEST" buttor. on receptacle. Verify zero voliage across receptacle hot and neutral. Reset GFI receptacle.

9.2.3.6 Turn cabinet enclosure light switci to the DI= positior.

9.2.3.7 Switch circuit breaker CB-6 to the OPEN position.

9.2.4 Cabinet Instrumentation

\subsubsection{Isolation Transformer}

9.2.4.1.1 Switch circuit breaker CB-7 to the CLOSE? positior.

9.2.4.1.2 Verify power is being supplied to tie isolation transformer ISO XFMER. Record primary and secondary vo tages.

\subsubsection{DC Power}

9.2.4.2.1 Set fused switch $F_{j-1}$ to the CLOSED position.

9.2.4.2.2 Verify power is jeing supplied to the $D C$ power source PS- $\$ 50$. Record AC input anc DC output voltages.

\subsubsection{F1ow Alarm System}

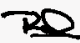

9.2.4.3.1 Set fused switch FU-13 to the CLOSEC position.

9.2.4.3.2 Set fused switch FU-3 to the CLOSEC position.

9.2.4.3.3 Visually verify insiruments are operating: Transmitter FIT-*57, Flow Al arm FSL $-\star 57$.

9.2.4.3.4 Verify zero voltage between PLC YYC-*0: Input Numider 2 and PLC $120 \mathrm{~V}$ Common.

9.2.4.3.5 Set fused switch FU-3 to tige OPE: position. 


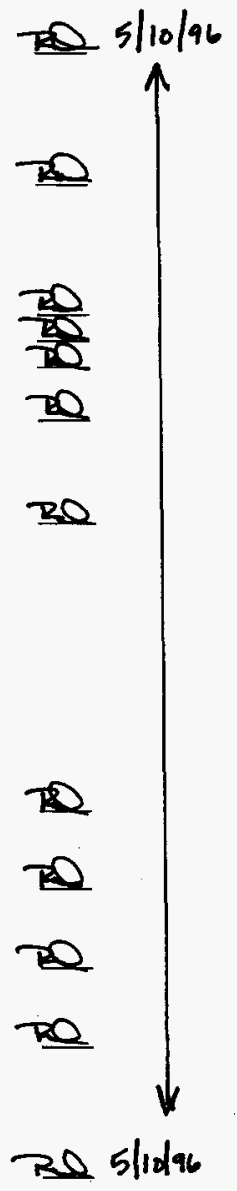
9.2.4.3.6 Set fused switch FU-13 to the OPEN position.

\subsubsection{Hydrogen Sensors}

9.2.4.4.1 Set fused switcines FU-2, FU-4, FU-5, aris FU-10 to the CLOSED position.

9.2.4.4.2 Visually verify instrument displays are operating:

Transmitter NIT-*54, Transmitter NIT-*55, Recorder NR- $* 54$.

9.2.4.4.3 Verify $120 \mathrm{~V}$ present between PLC YYC-*01 Input Number 0 and PLC $120 \mathrm{~V}$ Common and Input Number 1 and PLC $120 \mathrm{~V}$ Common.

9.2.4.4.4 Set fused switches FU-2, FU-4, FU-5, and FU-10 to the OPEN position.

\subsubsection{Sample Gas Heat Trace}

NOTE: These steps must be done in an expedited manner. The Heat Trace circuit may cause the sample gas temperature to rise at a fast rate. Adjust setpoints accordingly in order to prolong the test.

9.2.4.5.1 Set fused switch FU-6 to the CLOSED position.

9.2.4.5.2 Set circuit breaker CB-5 to the CLOSED position.

9.2.4.5.3 Visually verify controller TIC- $\star 50$ display is operating.

9.2.4.5.4 Adjust controlier temperature setpoint number I to a value at least 20 degrees above ambient temperature as indicated by the controller.

9.2.4.5.5 Adjust controller temperature setpoint number 2 to a value 5 degrees less than setpoint number 1 . 
WHC-SD-WM-ATR-143

REV. 0

PAGE 18 OF $2 \varepsilon$

$B \quad B$

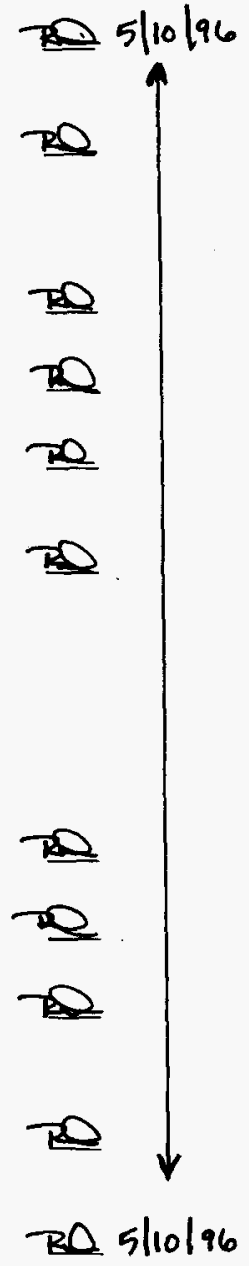

9.2.4.5.6 Verify no $A C$ voltage present between PLi YYC-*0I Input Number 5 and PLC $120 \mathrm{~V}$ Common.

9.2.4.5.7 Visually verify operation of neat trace HT $-\star 50$ circuit. Temperature value of sample gas should begin increasing. Record initial temperature and increased temperature of nominally 10 degrees.

9.2.4.5.8 Adjust setpoint 2 to 20 degrees below indicated temperature.

9.2.4.5.9 Verify $120 \mathrm{~V}$ present between PLC YYYC**? Input Number 5 and PLC $120 \mathrm{~V}$ Common.

9.2.4.5.10 Reset controller iemperature setpoint 1 to $125^{\circ} \mathrm{F}\left(52^{\circ} \mathrm{C}\right)$ and setpoint 2 to $65^{\circ}=$ $\left(18^{\circ} \mathrm{O}\right)$.

9.2.4.5.11 Set fused switch FJ-6 to the OPEN position.

\subsubsection{Calibration Gas Heat Trace}

NOTE: These steps must be cone in an expediteo manner. The Heat Trace circuit may cause the calibratior gas temperature to rise at a fast rate. Adjus: setpoints accordingly in order to prolong the test.

9.2.4.6.1 Set fused switch FU-7 to the CLOSEL

9.2.4.6.2 Visually verify controller TIC-*56 disp ay is operating.

9.2.4.6.3 Adjust contraller iemperature setpoint number 1 to a value at least 20 degrees above ambient temperature as indicated by the controllem.

9.2.4.6.4 Adjust controller temperature setpoint number 2 to a value 5 degrees less than setpoint number 1 .

9.2.4.6.5 Verify no AC voltage present between PLC YYC-*01 Input Number 4 and PLC $120 \mathrm{~V}$ Common. 


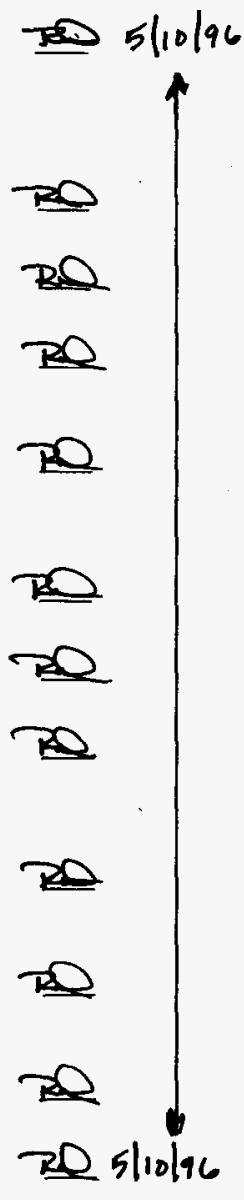
9.2.4.6.6 Visually verify operation of neat irace HT $-* 56$ circuit. Temperature value $0^{-}$ calibration gas should begin increasirs. Record initial temperature and increases temperature of nominally 10 degrees.
9.2.4.6.7 Adjust setpoint 2 to 20 oegrees be $i \pi$ indicateo temperature.

9.2.4.6.8 Verify $120 \mathrm{~V}$ present between PLC YYC- $\approx$ : Input Numjer 4 and PLC $120 \mathrm{~V}$ Common.

9.2.4.6.9 Reset controller iemperature setpoint 1 to $125^{\circ} \mathrm{F}\left(52^{\circ} \mathrm{C}\right)$ and setpoint 2 to $65^{\circ}=$ $\left(18^{\circ} \mathrm{C}\right)$.

9.2.4.6.10 Set fused switch FU-7 and circuit breaken CB-5 to the OPEN position.

\subsubsection{Cabinet Temperazure}

9.2.4.7.1 Set fused switch FU-8 to the CLOSEO position.

9.2.4.7.2 Visually verify temperature indicator TIS*62 display is operating.

9.2.4.7.3 Adjust controller temperature setpoiri: number 1 to a value at least 20 degrees above ambient temperature as indicated by the controller.

9.2.4.7.4 Adjust controller temperature setpoint number 2 to a value 20 degrees less than the indicated ambient temperature.

9.2.4.7.5 Verify 120V AC voltage present between PLC YYC-*01 Input Number 3 and PLC $120 \mathrm{~V}$ Common.

9.2.4.7.6 Adjust setpoint 2 to 10 degrees above indicated temperature.

9.2.4.7.7 Verify zero voltage present between PLC YYC-*0l Input Number 3 and PLC 120V Common. 


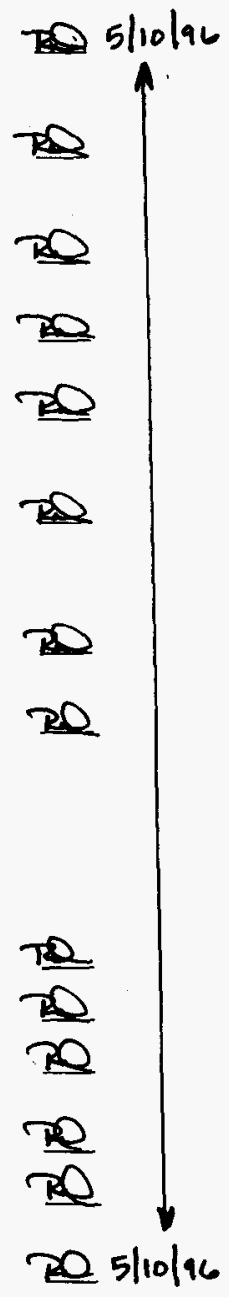

9.2.4.7.8 Adjust controller temperature setpoir: number 2 to a value 20 degrees less thar the indicated ambient temperature.

9.2.4.7.9 Verify $120 \mathrm{~V}$ AC voltage present between PL: YYC-*01 Input Numider 3 and PLC 120V Commor.

9.2.4.7.10 Adjust setpoint 1 to 10 jegrees jeiow indicated temperature.

9.2.4.7.11 Verify zero voltage present at PLC YYC-*01 Input Number 3 and PLC $120 \mathrm{~V}$ Common.

9.2.4.7.12 Reset controller temperature setpoint 1 ic $100^{\circ} \mathrm{F}\left(38^{\circ} \mathrm{C}\right)$ and setpoint 2 to $75^{\circ} \mathrm{F}$ $\left(24^{\circ} \mathrm{C}\right)$.

9.2.4.7.13 Set fuseo switch FU-8 to the OPEN positing.

\subsubsection{Alarm Systems}

9.2.4.8.1 Set fused switch FU-9 and FU-10 to tine CLOSED positior.

9.2.4.8.2 Depress Alarm Reset $P B-\star 51$ followed by the Horn Acknowleage pushbutton PB- $* 50$. (Due to lack of operating inputs the PLC may interpret alarm conditions exist.)

9.2.4.8.3 Depress and hold Alarm Test pushbutton PB$\star 52$. Verify the following conditiors exis:

Horn, YAH-*50, is ON.

High Hydrogen Beacon NAH-*55 is ON.

Open contacts Detween High Hydrogen Remote terminals TB2-21 and TB2-22.

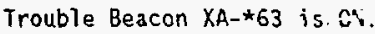

Open contacts between Cabinet iroub"e Remote terminals TB2-23 and TB2-24.

A11 Indicating Lights EXCEPT the RESE: SAMPLER light are $2 \%$. 


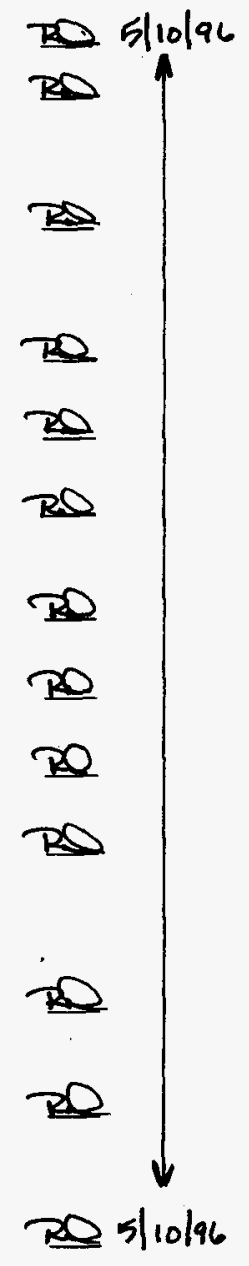

9.2.4.8.4 Release Alarm Test pushbuitior.

9.2.4.8.5 Depress Alarm Reset pushbutton PB-* 5 : followed oy the Horn Acknowledge pushbutton $\mathrm{PB}-\star 50$. Verify all inactive a' arms are reset.

9.2.4.8.6 Set fused switch FU-9 and FU-10 to the OPEN positior.

\subsubsection{Auto Sampler System}

9.2.4.9.1 Set fused switch FJ-10 to the CLOSEC position.

9.2.4.9.2 Depress the Reset Sampler pushbutton PB*58 located inside the enclosure.

9.2.4.9.3 Depress the Grab Sample pushbutton PB-*59 located inside the enclosure. Verify the following conditions exist:

The Grab Sample pushbutton light PBL-*59 is illuminated.

The Reset Sample pushbutton light PBL-*58 is illuminated.

The Reset Sample light YAL-*58 is illuminated.

9.2.4.9.4 After five minutes verify that the Grab Sample pushbutton 1 ight PBL- $* 59$ goes out and both the Reset Sample lights YAL- $* 58$ and the Reset Sample pushbutton 1ight PBL*58 remain on.

9.2.4.9.5 Depress the Grab Sample pushbutton PB- $* 59$ and verify that the Grab Sample pushbutton light remains out.

9.2.4.9.6 Depress the Reset Sample pushbutton PB-*58 and verify that both the Reset Sample light YAL $* 58$ and the Reset Sample pushbutton light $\mathrm{PBL}-* 58$ go out.

9.2.4.9.7 Set fused switch FU-10 to the OPEN position. 
WHC-5D-WM-ATR-143

REV. $=$

PAGE 22 OF 28

B $B$

\subsection{INTRINSIC SAFETY CIRCUITS}

9.3.1 Verify INTRINSIC SAFETY APPARATUS nameplates are located near intrinsic safety devices.

INTRINSIC SAFETY DEVICES:

$$
\begin{array}{lll}
N E-* 54 & \text { EB- } * 54 & \text { NIT-*52 } \\
\text { NE- } * 55 & \text { EB- } * 55 & \text { NIT }-* 55
\end{array}
$$

$\frac{R D}{5-10-96}$

9.3.2 Verify intrinsic safety wiring is labeled per NFPA-70 Section 504-80 and ISA RP 12.6.

INTRINSIC SAFETY WIRING: (Wiring between the fo ": owing devices;

$\mathrm{EB}-* 54 / \mathrm{NE}-* 54$

$\mathrm{EB}-* 55 / \mathrm{NE}-* \frac{5}{5}$

$2 \mathrm{PO}$

5-10-96

9.3.3 Verify resistance between intrinsic safety single poir: field ground and intrinsic safety device ground is less than one ohm. Record value.

\subsection{REVIEH}

Check that all steps have been completed.

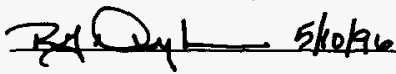


WHC-SD-WM-ATR-143

REV. 0

PAGE 23 OF 28

$B \quad B$

\subsection{PNEUMATIC SYSTEMS}

This procedure will demonstrate that all process lines and devices function proper'y.

\subsection{PIPING}

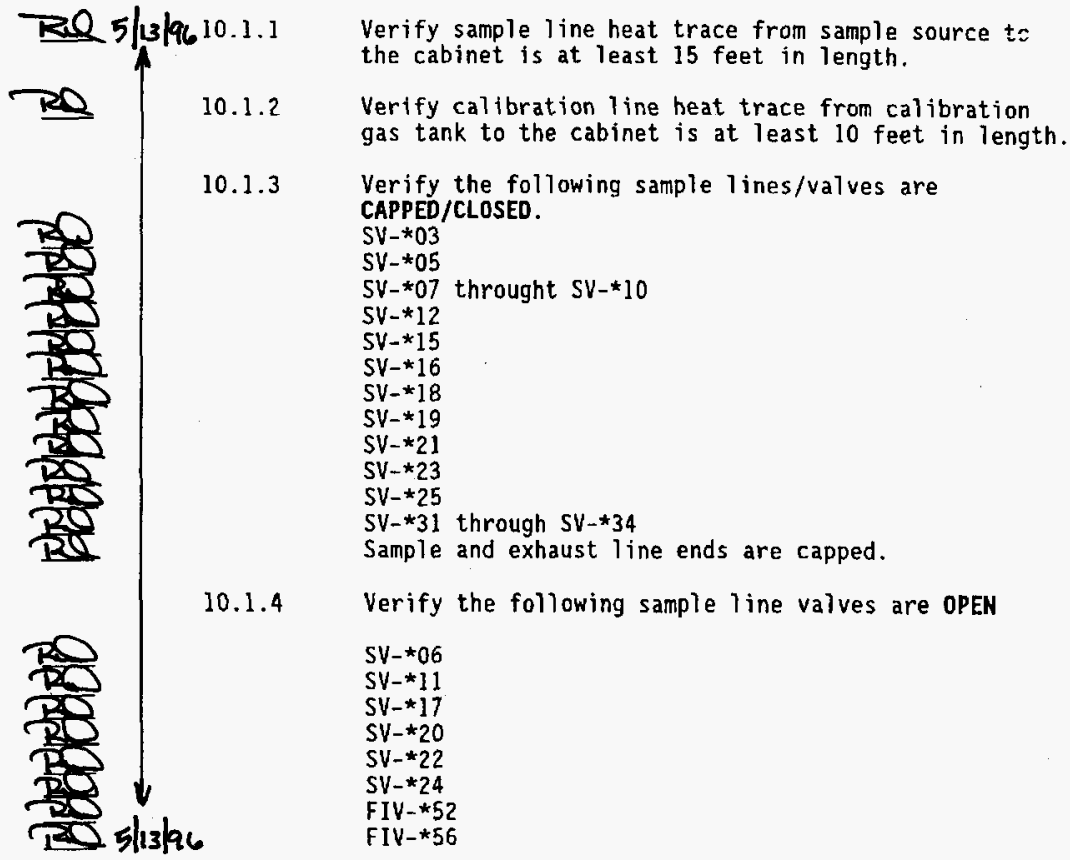

10.2 SAMPLE MAIN FLOW LOOP

DS S|13|+610.2.1 Set fused switch FU-13 to the CLOSED position. 
WHC-SD-WM-ATR-143

REV. 0

PAGE 24 OF 28

B 8

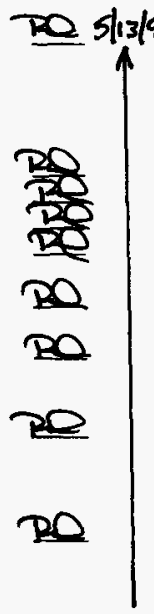

10.2 .2

Remove end caps from sampie inlet and outlet lines, Take care in not allowing foreign objects to enter lines.

10.2.3 OPEN valves:

$\mathrm{SV}-\star_{03}$

$S V-* 05$

$S V-\star 16$

$S V-\star 25$

10.2.4 Switch circuit oreaker CB-3 to tive CLOSED position.

10.2.5 Adjust flow control valve SV- ${ }^{24}$ to nominally 5" $\mathrm{H}_{2} \mathrm{O}$ as indicated on FIT-*5?.

10.2.6 Verify air is being extracted from the sample inlet line and air is being exhausted through the samp.e outlet line.

10.2.7 Verify the pressure differential indicator PDI-*5: indicates an upscale reading of less than $40^{\prime \prime} \mathrm{H}_{2} \mathrm{i}$.

\subsection{AUTO GRAB SAMPLING LOOF}

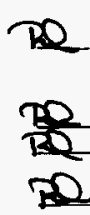

10.3 .1

Set fuseo switch FU-10 to the CLOSED position.

10.3 .2

OPEN Vaives:

$S V-\star 15$

Gas Sample Assembly Valves

10.3.3 Depress the Grab Samp e pusinbutton PB $\star 59$. Veri $=y$ that FIV $-\star 52$ indicates ${ }^{-} \mathrm{cir}$.

10.3.4 Adjust F[V-*52 to nominally $10 \%$ flow.

10.3.5 CLOSE valves SV-* 16 and SV-*25. Verify that FIV-*5e still indicates F" sin.

10.3.6 OPEN valves SV-* 16 and $S V-\star 25$. CLOSE valve SV-*15. Verify that FIV- $\star 52$ indicates no flow.

10.3.7 Depress the Reset Sample pushbutton PB-*55.

PQ Set fused switch FU-10 to the OPEN positior. 
WHC-SD-WM-ATP-143

REV. 0

PAGE 25 OF 28

B B

\subsection{CALIBRATION LOOP}

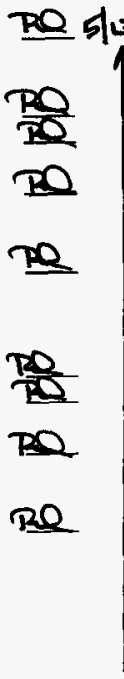

Remove plug to atmosphere upstream of FLT $-* 55$.

10.4.2 OPEN valves:

SV-*1B

$S V-* 31$

10.4.3 Adjust to nominally $2.0 \mathrm{cfh}$ flow torough: FIV- $\star 5 E$.

10.4.4 CLOSE valves SV-*18 and SV-*31. Verify that FIV- $* 56$ indicates zero flow.

10.4.5 OPEN valves:

SV-*15

SV-*3:

10.4.6 Adjust to nominally $2.0 \mathrm{cfh}$ flow through FIV $-\star 5 \div$.

10.4.7 CLOSE vaives SV $* 19$ and SV-*31. Verify that FIV-*56 indicates zero flow.

\subsection{ANALYTIC INSTRUMENT LOOP}

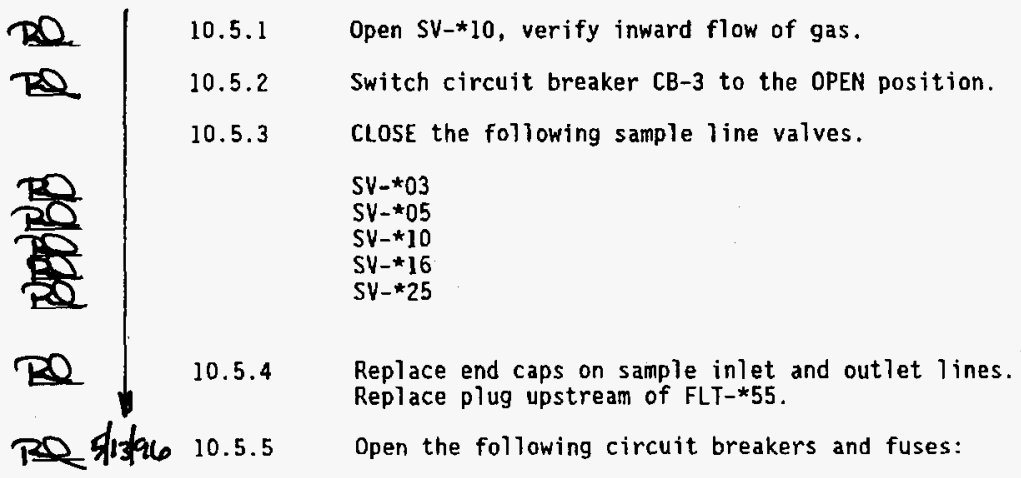


WHC-SD-WM-ATR-143

REV. $气$

PAGE 26 OF 28

B 8

20 513196

Re $5 / 139610.5 .6$
CB-1 throught $\mathrm{CB}-7$

FU-1 through FU-13

De-energize power source to the Standard Hyoroger. Monitoring 5ystem. Refer to H-14-100297, Standard-C Hydrogen Monitoring System One Line \& Elementary Diagrams.

\subsection{REVIEW}

Check that all steps have been completed.

Reftaplate III AI


WHC-SD-WM-ATR-143

REV. :

PAGE 27 OF 25

$8 B$

\subsection{DATA SHEETS}

\subsection{TEST DATA SHEETS}

The Test Data Sheets are used to document any procedure step requiring verification. A description of the data sheet format follows.

1. Date--Record the date the test is performed.

2. Title of Test--There are two tests being performed by this procedure, the Electrical Systems test and the Pneumatic Systems test.

3. SHMS Unit Number--Record the unit number of the Standard Hydrogen Monitoring System.

4. Equipment Serial Number(s)--Record the serial numbers of any device used during the tests.

5. Test Performed By--Print the name of the craftsman performing the test.

6. Procedure Number--This column contains the test steps requiring verification.

7. Item--This column contains the item being verified, e.g., Pump, Air Conditioner, Heater, etc.

8. Value--This column contains the quantitative or qualitative measure of the item being verified, i.e. a line voltage may have a value of $120 \mathrm{~V}$, whereas a pump may have a value of ON or OFF.

9. Bange--This column indicates the anticipated value of the item being measured.

10. Accept/Reject--Indicate whether the value obtained is acceptable in comparison with the Range.

11. Comment--If the value is rejected, give a justification for denial.

Test Data Sheets are included in Appendix $A$.

\subsection{TEST EXCEPTION SHEET}

Exception Data Sheets are used to document exceptions to the test procedure. Actions taken regarding disposition are noted on the exception sheet. Typical dispositions are: 
WHC-SD-WM-ATR-143

REV. 0

PAGE 28 OF 26

B 8

1. Test approved with exception (i.e. rerun of tine acceptance test unnecessary).

2. Entire acceptance test to be repeated after the discrepancy ias jeen corrected.

3. Acceptance Test Procedure step(s) affected to be repeated after tine discrepancy ias been correctę.

Test Exception Sinets are included in Appendix E.

\subsection{TEST LOG SHEET}

Test $\log$ Sineets are used to document test start and stop times ars is document any other notes concerning the execution of the Acceptance est Procedure.

Test Log Sheets are included in Appendix $C$. 
WHC-SD-WM-ATR-14?

REV. $C$

PAGE AI OF A7

$B$ B

APPENDIX A: TEST DATA SHEETS

TEST DATA SHEE:

\begin{tabular}{|c|c|c|c|c|c|}
\hline \multicolumn{3}{|c|}{$5-10-96$} & \multicolumn{3}{|c|}{ sHMs unit number: VTP-PNL-105 K } \\
\hline \multicolumn{3}{|c|}{$\begin{array}{l}\text { Titte of Test: } \\
\text { Electrical Systems }\end{array}$} & \multirow{2}{*}{\multicolumn{3}{|c|}{$\begin{array}{l}\text { Equipment Serial Number(s): } \\
\qquad 06464\end{array}$}} \\
\hline \multicolumn{3}{|c|}{$\begin{array}{l}\text { Test Performed By: } \\
\text { B.LL Wiates ICF-KH }\end{array}$} & & & \\
\hline $\begin{array}{l}\text { Procedure } \\
\text { Number }\end{array}$ & Item & value & Range & $(A / R)$ & Comment \\
\hline 9.1 .1 & Resistance & 0 & $<10 \mathrm{hm}$ & A & \\
\hline 9.1 .3 & $\begin{array}{l}\text { Line } \\
\text { Voltages: } \\
\text { L1 } \\
\text { L2 } \\
N\end{array}$ & $\begin{array}{l}122 \\
122 \\
0\end{array}$ & $\begin{array}{l}1, L 2: \\
120 \mathrm{~V} \pm 5 \% \\
\mathrm{~N}: \text { oV }\end{array}$ & A & \\
\hline 9.2 .1 .4 & $\begin{array}{l}A C-\star 60 \& \\
H T R-\star 60\end{array}$ & 60 & $\begin{array}{l}\text { A/C } \\
\text { Compressor } \\
\text { ON, Heater } \\
\text { OFF }\end{array}$ & $\boldsymbol{A}$ & \\
\hline 9.2 .1 .6 & $A C-\star 60$ & 60 & $\begin{array}{l}\text { A/C } \\
\text { Compressor } \\
\text { OFF }\end{array}$ & A & \\
\hline 9.2 .1 .8 & HTR-*60 & 60 & Heater ON & $\Delta$ & \\
\hline 9.2 .1 .10 & $\begin{array}{l}A C-\star 60 \& \\
\text { HTR }-\star 60\end{array}$ & 60 & $\begin{array}{l}\text { A/C } \\
\text { Compressor } \\
\text { ON, Heater } \\
\text { OfF }\end{array}$ & $A$ & \\
\hline 9.2 .2 .3 & $P-\star 50$ & $\longrightarrow$ & Pump ON & A & \\
\hline 9.2 .3 .3 & LTI & 一 & Light $\mathrm{ON}$ & A & \\
\hline 9.2 .3 .4 & $\begin{array}{l}\mathrm{RCPT}: \\
\mathrm{H} / \mathrm{ZI} \\
\mathrm{N}\end{array}$ & 121 & 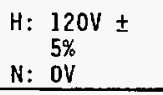 & $A$ & \\
\hline 9.2 .3 .5 & $\begin{array}{l}\text { RCPT: } \\
H \quad 12 \mid \\
\mathrm{N}\end{array}$ & 121 & $\begin{array}{l}\mathrm{H}: \mathrm{OV} \\
\mathrm{N}: \mathrm{OV}\end{array}$ & $A$ & \\
\hline
\end{tabular}


WHC-SD-WM-ATR-143

REV. C

PAGE A2 OF A?

$B \quad B$

TEST DATA SHEE:

\begin{tabular}{|c|c|c|c|c|c|}
\hline \multicolumn{3}{|c|}{$5-10-96$} & \multicolumn{3}{|c|}{ SHus Unit Humber: VTP-PNL-105K } \\
\hline \multicolumn{3}{|c|}{$\begin{array}{l}\text { ritle of Test: } \\
\text { Electrical Systems }\end{array}$} & \multirow{2}{*}{\multicolumn{3}{|c|}{$\begin{array}{l}\text { Equipment Serial Mumber(s): } \\
\qquad \begin{array}{l}\text { Olo } 464\end{array}\end{array}$}} \\
\hline \multicolumn{3}{|c|}{ 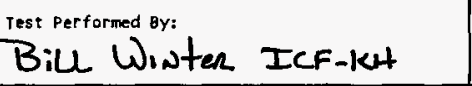 } & & & \\
\hline $\begin{array}{l}\text { Procedure } \\
\text { Number }\end{array}$ & Item & value & Range & $(A / R)$ & Comment \\
\hline 9.2 .4 .1 .2 & $\begin{array}{l}\text { XFMR1: } \\
\text { Primary } \\
\text { Secondary }\end{array}$ & $\begin{array}{l}121 v \\
124 v \\
\end{array}$ & $\begin{array}{l}\text { Primary, } \\
\text { Secondary: } \\
120 \mathrm{~V} \pm 5 \%\end{array}$ & $A$ & \\
\hline 9.2 .4 .2 .2 & $\begin{array}{l}\text { PS- } \star 50: \\
A C \text { In } \\
\text { DC Out }\end{array}$ & $\begin{array}{l}126 V \\
25 V\end{array}$ & $\begin{array}{l}\text { Incoming } \\
A C: \\
120 \mathrm{~V} \pm 5 \% \\
\text { Outgoing } \\
D C: \\
24 \mathrm{~V} \pm 5 \%\end{array}$ & A & \\
\hline 9.2 .4 .3 .3 & $\begin{array}{l}\text { Visual: } \\
\text { FIT-*57 } \\
\text { FSL-*57 }\end{array}$ & $\begin{array}{l}O K \\
\text { OK }\end{array}$ & $\begin{array}{l}\text { Power } \\
\text { Indication } \\
\text { Lights on }\end{array}$ & & \\
\hline 9.2 .4 .3 .4 & $\begin{array}{l}Y Y C-\star 01 \text { In } \\
\# 2 \text { Volt age: }\end{array}$ & 0 & ov & & \\
\hline 9.2 .4 .4 .2 & $\begin{array}{l}\text { NIT } * 554 \\
\text { NIT-*55 } \\
\text { NR- *54 }\end{array}$ & $\begin{array}{l}\text { ok } \\
\text { ok } \\
\text { OK }\end{array}$ & $\begin{array}{l}\text { Displays } \\
\text { powered } 0 N \text {. }\end{array}$ & $f$ & \\
\hline 9.2 .4 .4 .3 & $\begin{array}{l}\text { YYC-*01 } \\
\text { In \#0 } \\
\text { In \#1 } \\
\text { Voltage: }\end{array}$ & $\begin{array}{l}125 V \\
125 V\end{array}$ & $120 \mathrm{~V} \pm 5 \%$ & $A$ & \\
\hline 9.2 .4 .5 .3 & TIC $-\star 50$ & ok & $\begin{array}{l}\text { Display } \\
\text { powered oN. }\end{array}$ & A & \\
\hline 9.2 .4 .5 .6 & $\begin{array}{l}Y Y C-\star 01 \text { In } \\
\# 5 \text { Volt tage: }\end{array}$ & 0 & OV & A & \\
\hline 9.2 .4 .5 .7 & $\begin{array}{l}\text { HT-*50: } \\
\text { InitiaT } \\
\text { Temp. } \\
\text { Final Temp. }\end{array}$ & $\begin{array}{l}82 \\
85\end{array}$ & $\begin{array}{l}\text { Final Temp. } \\
=\text { Initial } \\
\text { Temp. + } \\
10^{\circ} \mathrm{F}\end{array}$ & $A$ & \\
\hline
\end{tabular}


WHC-SD-WM-ATR-143

REV. $=$

PAGE A3 OF $A 7$

$B \quad B$

TEST DATA SHEET

\begin{tabular}{|c|c|c|c|c|c|}
\hline \multicolumn{3}{|c|}{ Date: $5-10,96$} & \multicolumn{3}{|c|}{ SHMS Unit Number: VTP-PNL- $105 \mathrm{~K}$} \\
\hline \multicolumn{3}{|c|}{$\begin{array}{l}\text { Title of Test: } \\
\text { Electrical Systems }\end{array}$} & \multirow{2}{*}{\multicolumn{3}{|c|}{$\begin{array}{l}\text { Equipment Serial Number(s): } \\
\qquad 06464\end{array}$}} \\
\hline \multicolumn{3}{|c|}{$\begin{array}{l}\text { Test Performed By: } \\
\text { Bill Winten ICF-KH }\end{array}$} & & & \\
\hline $\begin{array}{c}\text { Procedure } \\
\text { Mumber } \\
\end{array}$ & Iten & value & Renge & $(A / R)$ & Coment \\
\hline 9.2 .4 .5 .9 & $\begin{array}{l}Y Y C-\star 01 \text { In } \\
\# 5 \text { Voltage: }\end{array}$ & $125 \mathrm{~V}$ & $120 \mathrm{~V} \pm 5 \%$ & $A$ & \\
\hline 9.2 .4 .6 .2 & $\mathrm{TIC}-\star 56$ & $\alpha k$ & $\begin{array}{l}\text { Display } \\
\text { powered oN. }\end{array}$ & A & \\
\hline 9.2 .4 .6 .5 & $\begin{array}{l}\text { YYC-*01 In } \\
\# 4 \text { Voltage: }\end{array}$ & 0 & ov & A & \\
\hline 9.2 .4 .6 .6 & $\begin{array}{l}\text { HT-*56: } \\
\text { Initial } \\
\text { Temp. } \\
\text { Final Temp. }\end{array}$ & $\begin{array}{l}104 \\
112\end{array}$ & $\begin{array}{l}\text { Final Temp. } \\
=\text { Initial } \\
\text { Temp }+10^{\circ} \mathrm{F}\end{array}$ & A & \\
\hline 9.2 .4 .6 .8 & $\begin{array}{l}\text { YYC-*01 In } \\
\# 4 \text { Voltage: }\end{array}$ & $124 r$ & $120 \mathrm{~V} \pm 5 \%$ & A & \\
\hline 9.2 .4 .7 .2 & TIS-*62 & OK & $\begin{array}{l}\text { Display } \\
\text { powered ON. }\end{array}$ & A & \\
\hline 9.2 .4 .7 .5 & $\begin{array}{l}\text { YYC-*01 In } \\
\# 3 \text { Volt tage: }\end{array}$ & $124 v$ & $120 \mathrm{~V} \pm 5 \%$ & A & \\
\hline 9.2 .4 .7 .7 & $\begin{array}{l}\text { YYC-*01 In } \\
\# 3 \text { Voltage: }\end{array}$ & 0 & ov & A & \\
\hline 9.2 .4 .7 .9 & $\begin{array}{l}\text { YYC-*01 In } \\
\# 3 \text { Voltage: }\end{array}$ & $124 v$ & $120 \mathrm{~V} \pm 5 \%$ & A & \\
\hline 9.2 .4 .7 .11 & $\begin{array}{l}Y Y C-* 01 \text { In } \\
\# 3 \text { Voltage: }\end{array}$ & D & ov & A & \\
\hline
\end{tabular}


WHC-SD-WM-ATR-143

REV. 0

PAGE A4 OF AT

B $B$

TEST DATA SHEET

\begin{tabular}{|c|c|c|c|c|c|}
\hline \multicolumn{3}{|c|}{$5-10-96$} & \multicolumn{3}{|c|}{ SHMS Unit Number: VTP-PNL-105K } \\
\hline \multicolumn{3}{|c|}{$\begin{array}{l}\text { Title of Test: } \\
\text { Electrical systems }\end{array}$} & \multirow{2}{*}{\multicolumn{3}{|c|}{$\begin{array}{l}\text { Equipment serial Number(s): } \\
\qquad 064 / 64\end{array}$}} \\
\hline \multicolumn{3}{|c|}{$\frac{\text { Test performed By: }}{\text { Bill Winter ILF-KH }}$} & & & \\
\hline $\begin{array}{l}\text { Procedure } \\
\text { Number }\end{array}$ & It tem & Value & Range & $(A / R)$ & Comment \\
\hline 9.2 .4 .8 .3 & 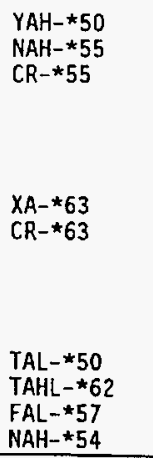 & $\begin{array}{l}\text { ON } \\
\text { ON } \\
0 \\
\text { ON } \\
\text { on } \\
\text { ON } \\
\text { ON } \\
\text { DN } \\
\text { ON }\end{array}$ & $\begin{array}{l}\text { ON } \\
\text { ON } \\
\text { Infinite } \\
\text { Resistance } \\
\text { Between } \\
\text { TB2-21 and } \\
\text { TB2-22. } \\
\text { ON } \\
\text { Infinite } \\
\text { Resistance } \\
\text { Between } \\
\text { TB2-23 and } \\
\text { TB2-24. } \\
\text { ON } \\
\text { ON } \\
\text { ON } \\
\text { ON }\end{array}$ & $\hat{A}$ & \\
\hline 9.2 .4 .8 .5 & $\begin{array}{l}\text { Inactive } \\
\text { Alarms }\end{array}$ & OFF & OFF & $A$ & \\
\hline 9.2 .4 .9 .3 & $\begin{array}{l}\text { PBL-*59 } \\
\text { PBL-*58 } \\
\text { YAL-*58 }\end{array}$ & $\begin{array}{l}\text { ON } \\
\text { ON } \\
\text { ON }\end{array}$ & $\begin{array}{l}\text { ON } \\
\text { ON } \\
\text { ON }\end{array}$ & $\begin{array}{l}A \\
A\end{array}$ & \\
\hline 9.2 .4 .9 .4 & 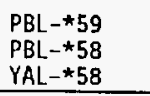 & $\begin{array}{l}\text { DFF } \\
\text { ON } \\
\text { ON }\end{array}$ & $\begin{array}{l}\text { OFF } \\
\text { ON } \\
\text { ON }\end{array}$ & & \\
\hline 9.2 .4 .9 .5 & PBL-*59 & OFF & OFF & A & \\
\hline 9.2 .4 .9 .6 & $\begin{array}{l}\mathrm{PBL}-\star 58 \\
\mathrm{YAL}-\star 58 \\
\end{array}$ & $\begin{array}{l}\text { OFF } \\
\text { OFF }\end{array}$ & $\begin{array}{l}\text { OFF } \\
\text { OFF }\end{array}$ & 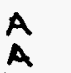 & \\
\hline 9.3 .1 & Nameplates & OK & $\begin{array}{l}\text { Near Is } \\
\text { Devices. }\end{array}$ & $\mathbf{A}$ & \\
\hline
\end{tabular}




$$
\begin{array}{r}
\text { WHC-SD-WM-ATR-143 } \\
\text { REV. C } \\
\text { PAGE AF OF AT } \\
B \quad B
\end{array}
$$

TEST DATA SHEET

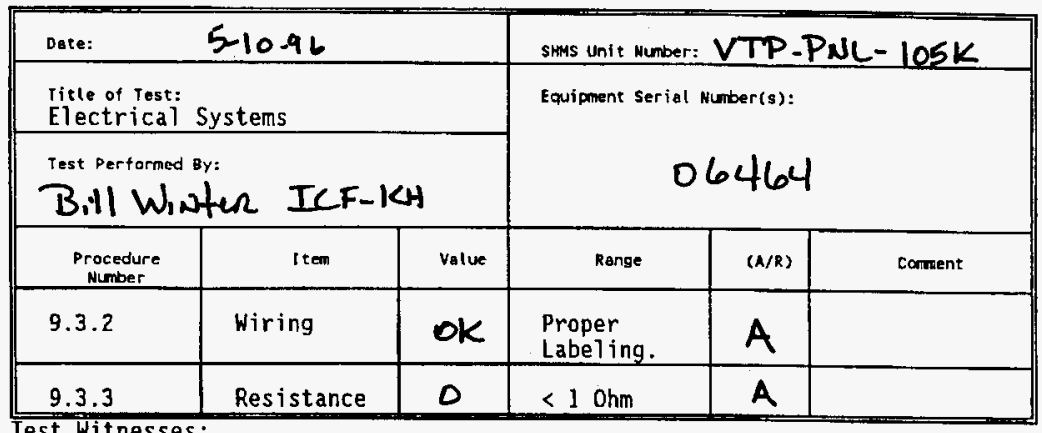

Test Witnesses:

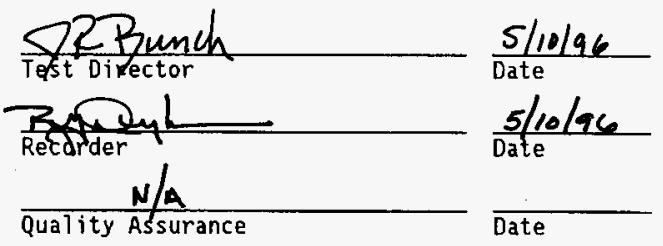


WHC-SD-WM-ATR- - $\$ 3$

REV. 0

PAGE AG OF AT

TEST DATA SHEET

$B \quad B$

\begin{tabular}{|c|c|c|c|c|c|}
\hline \multicolumn{3}{|c|}{ Date: $5 / 13 / 96$} & SyMs Unit Munbe & \multicolumn{2}{|c|}{ VTP.PNL-10SK } \\
\hline \multicolumn{3}{|c|}{$\begin{array}{l}\text { Title of rest: } \\
\text { Pneumatic Systems }\end{array}$} & \multirow{2}{*}{\multicolumn{3}{|c|}{$\begin{array}{l}\text { Equlpment Serial Mumber(s): } \\
\qquad N / A\end{array}$}} \\
\hline \multicolumn{3}{|c|}{$\begin{array}{l}\text { Test Performed By: } \\
\text { JA Bottemillee }\end{array}$} & & & \\
\hline $\begin{array}{l}\text { Procedure } \\
\text { Number }\end{array}$ & Item & value & Range & $\left(\begin{array}{ll}(K) \\
R)\end{array}\right.$ & comment \\
\hline 10.1 .1 & $\begin{array}{l}\text { Sample Line } \\
\text { Heat Trace } \\
\text { Length }\end{array}$ & $>15$ & $>15$ Feet & A & \\
\hline 10.1 .2 & $\begin{array}{l}\text { Calibration } \\
\text { line Heat } \\
\text { Trace } \\
\text { Length }\end{array}$ & $>10$ & $>10$ Feet & A & \\
\hline 10.1 .3 & $\begin{array}{l}\text { Sample Line } \\
\text { Valves }\end{array}$ & $\Delta K$ & CLOSED & A & \\
\hline 10.2 .6 & $\begin{array}{l}\text { Sample } \\
\text { Intake \& } \\
\text { Exhaust }\end{array}$ & $\begin{array}{l}\text { OK } \\
\text { OK }\end{array}$ & $\begin{array}{l}\text { Air going } \\
\text { in through } \\
\text { Intake, } \\
\text { leaving } \\
\text { through } \\
\text { Exhaust }\end{array}$ & $\begin{array}{l}\text { A } \\
A\end{array}$ & \\
\hline 10.2 .7 & PDI $-* 51$ & $<40$ & $<40^{\prime \prime} \mathrm{H}_{2} \mathrm{O}$ & $A$ & \\
\hline 10.3 .3 & FIV $-\star 52$ & ok & $\begin{array}{l}\text { Indicates } \\
\text { Flow }\end{array}$ & $A$ & \\
\hline 10.3 .6 & FIV $-* 52$ & $\phi$ & $\begin{array}{l}\text { Indicates } \\
\text { No Flow }\end{array}$ & $A$ & \\
\hline 10.4 .4 & FIV $-* 56$ & $\phi$ & Zero Flow & $A$ & \\
\hline 10.4 .7 & FIV $-* 56$ & $\phi$ & Zero Flow & $A$ & \\
\hline 10.5 .1 & $S V-\star 10$ & ok & $\begin{array}{l}\text { Air flow } \\
\text { into } \\
\text { system }\end{array}$ & $A$ & \\
\hline
\end{tabular}


WHC-SD-WM-ATR-143

REV. 0

Test Witnesses:

QR. Bunch

PAGE AT OF AT

B $B$

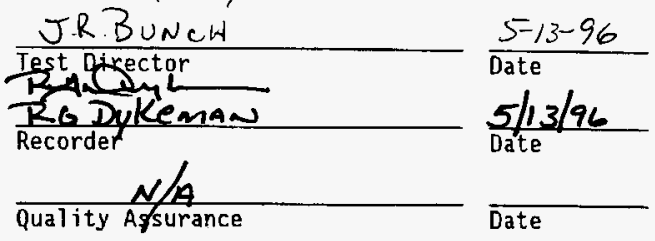


WHC-SD-WM-ATR-143

REV. 0

PAGE BI OF BI

APPENDIX B: TEST EXCEPTION SHEETS

$B \quad B$

TEST EXCEPTION SHEET

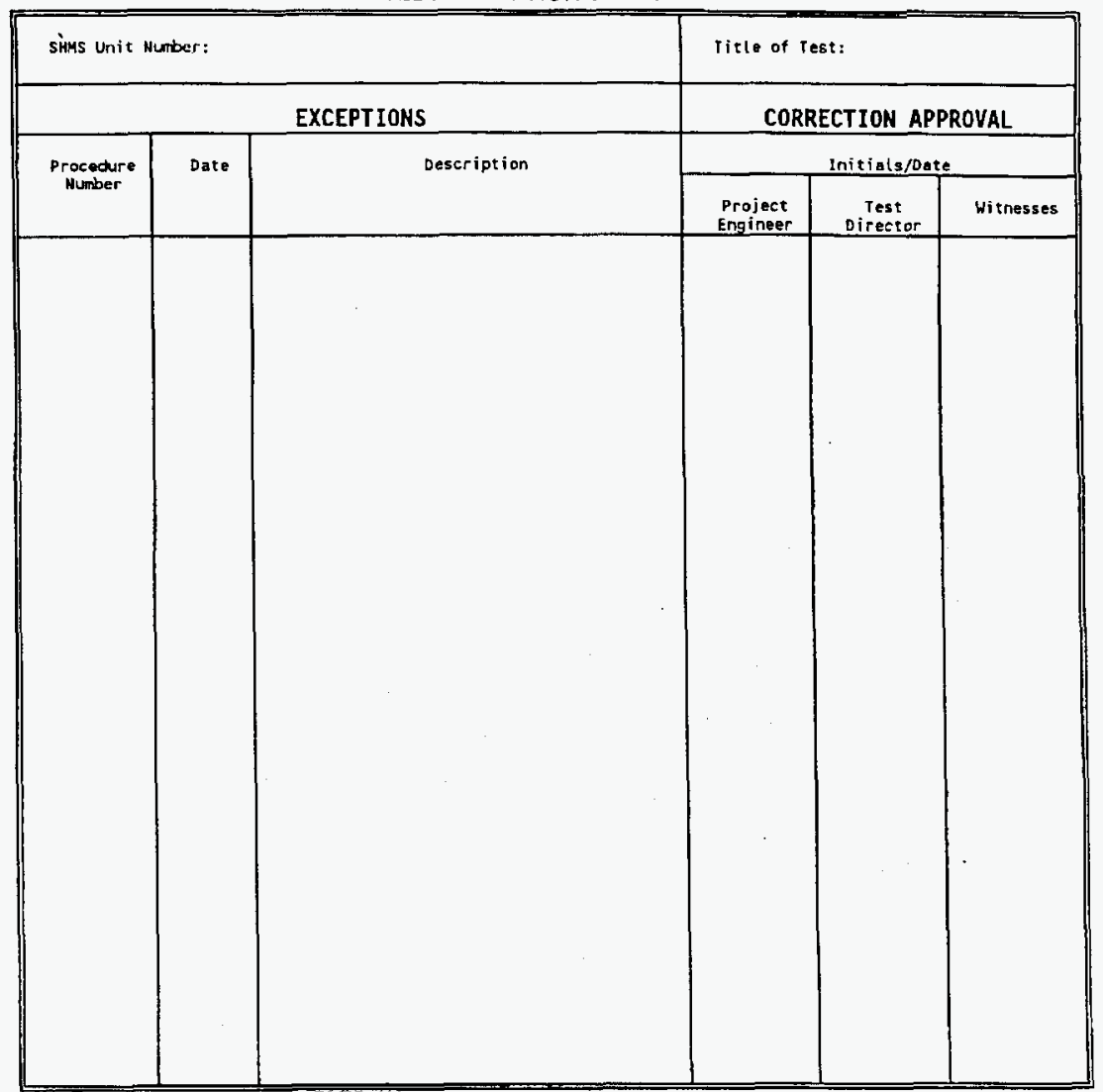

IEST APPROVED WITH EXCEPTIONS

\begin{tabular}{lr}
\hline WHC Project Engineer \\
\hline Recorder & Date \\
\hline Witness & Date
\end{tabular}

Date

Witness

Date 
APPENDIX C: TEST LOG SHEE

WHC-SD-WM-ATR- 143

REV 0

PAGE $\mathrm{Cl}$ OF $\mathrm{Cl}$

B B

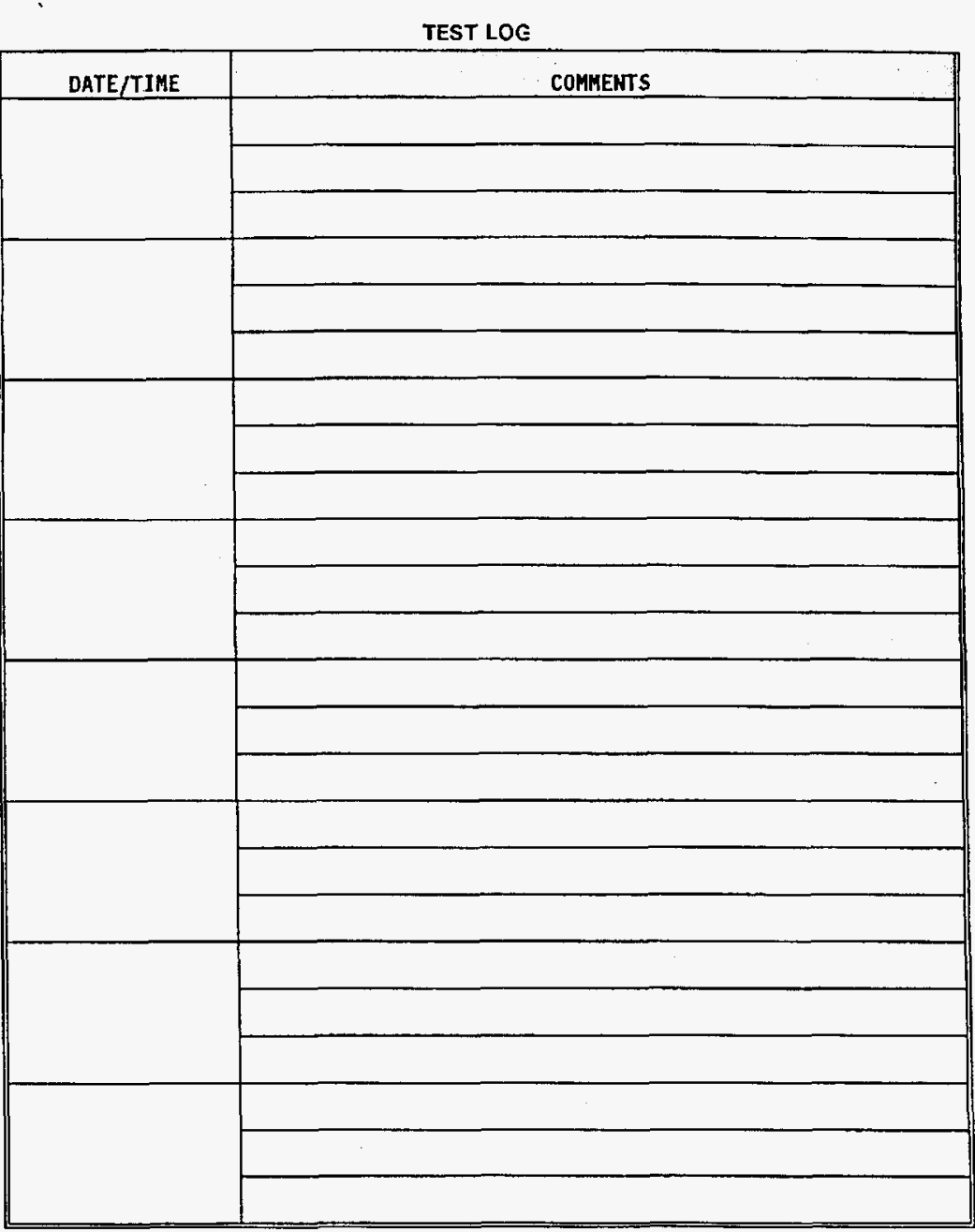




\section{DISTRIBUTION SHEET}

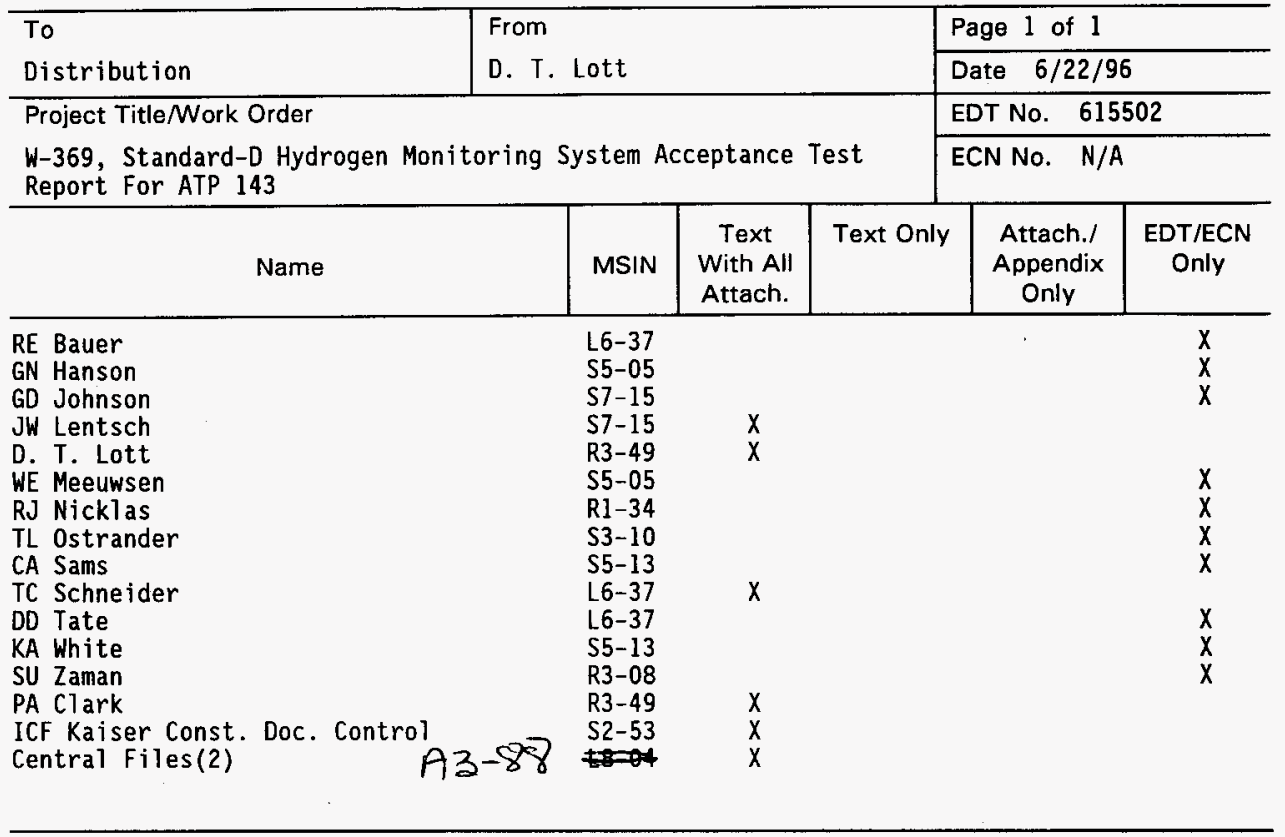

